OPEN ACCESS

Edited by:

Juan Aguirre,

Universidad de Chile, Chile

Reviewed by:

Martin Wiedmann,

Cornell University, USA

Sangwei Lu,

University of California, Berkeley, USA

*Correspondence:

Florence Baron

florence.baron@agrocampus-ouest.fr

Specialty section: This article was submitted to

Food Microbiology,

a section of the journal

Frontiers in Microbiology

Received: 03 January 2017 Accepted: 24 April 2017

Published: 12 May 2017

Citation:

Baron F, Bonnassie S, Alabdeh M, Cochet M-F, Nau F, Guérin-Dubiard C,

Gautier M, Andrews SC and Jan S (2017) Global Gene-expression

Analysis of the Response of

Salmonella Enteritidis to Egg White

Exposure Reveals Multiple Egg

White-imposed Stress Responses.

Front. Microbiol. 8:829.

doi: 10.3389/fmicb.2017.00829

\section{Global Gene-expression Analysis of the Response of Salmonella Enteritidis to Egg White Exposure Reveals Multiple Egg White-imposed Stress Responses}

Florence Baron ${ }^{1,2 *}$, Sylvie Bonnassie ${ }^{1,2,3}$, Mariah Alabdeh $^{1,2}$, Marie-Françoise Cochet $^{1,2}$, Françoise Nau ${ }^{1,2}$, Catherine Guérin-Dubiard ${ }^{1,2}$, Michel Gautier ${ }^{1,2}$, Simon C. Andrews ${ }^{4}$ and Sophie Jan ${ }^{1,2}$

${ }^{1}$ Agrocampus Ouest, UMR1253 Science et Technologie du Lait et de l'Oeuf, Rennes, France, ${ }^{2}$ INRA, UMR1253 Science et Technologie du Lait et de l'Oeuf, Rennes, France, ${ }^{3}$ Science de la Vie et de la Terre, Université de Rennes I, Rennes, France,

${ }^{4}$ School of Biological Sciences, University of Reading, Reading, UK

Chicken egg white protects the embryo from bacterial invaders by presenting an assortment of antagonistic activities that combine together to both kill and inhibit growth. The key features of the egg white anti-bacterial system are iron restriction, high $\mathrm{pH}$, antibacterial peptides and proteins, and viscosity. Salmonella enterica serovar Enteritidis is the major pathogen responsible for egg-borne infection in humans, which is partly explained by its exceptional capacity for survival under the harsh conditions encountered within egg white. However, at temperatures up to $42^{\circ} \mathrm{C}$, egg white exerts a much stronger bactericidal effect on $S$. Enteritidis than at lower temperatures, although the mechanism of egg white-induced killing is only partly understood. Here, for the first time, the impact of exposure of $S$. Enteritidis to egg white under bactericidal conditions $\left(45^{\circ} \mathrm{C}\right)$ is explored by global-expression analysis. A large-scale (18.7\% of genome) shift in transcription is revealed suggesting major changes in specific aspects of $S$. Enteritidis physiology: induction of egg white related stress-responses (envelope damage, exposure to heat and alkalinity, and translation shutdown); shift in energy metabolism from respiration to fermentation; and enhanced micronutrient provision (due to iron and biotin restriction). Little evidence of DNA damage or redox stress was obtained. Instead, data are consistent with envelope damage resulting in cell death by lysis. A surprise was the high degree of induction of hexonate/hexuronate utilization genes, despite no evidence indicating the presence of these substrates in egg white.

Keywords: egg white, Salmonella Enteritidis, transcriptomic, envelop stress, iron

\section{INTRODUCTION}

Avian egg white is an intracellular fluid that serves the dual purposes of protecting the developing embryo against invading microorganisms and providing it with a source of nutrients. Egg white represents a hostile medium for bacterial propagation due to its harsh physicochemical properties (alkaline $\mathrm{pH}$ and high viscosity), the nutritional restriction it imposes and its arsenal of 
antimicrobial molecules. Various macromolecules within egg white exhibit antimicrobial activity (Baron et al., 2016 for a review), including: lysozyme, which exerts a hydrolytic activity against the cell wall of Gram-positive bacteria leading to membrane disruption; ovotransferrin, a high-affinity ironchelating protein that promotes iron restriction and mediates damage to bacterial cytoplasmic membranes; protease inhibitors (e.g., ovomucoid, ovoinhibitor, cystatin, and ovostatin) that inhibit proteases of pathogenic bacteria required for host colonization; and vitamin-binding proteins (flavoprotein, avidin, and the thiamine-binding protein) which sequester riboflavin, biotin, and thiamine, respectively, and thus induce bacteriostasis. In addition, some minor proteins and peptides recently revealed by high-throughput approaches may also play a role in defense against bacterial contamination and it is quite possible that the various anti-bacterial factors associated with egg white interact synergistically to enhance protection against bacterial invaders (Baron et al., 2016).

Studies on the antimicrobial activity of egg white generally employ Salmonella enterica serovar Enteritidis as the model bacterium as it represents the predominant (90\%) serotype responsible for foodborne diseases (salmonellosis) resulting from egg or egg-product consumption (EFSA BIOHAZ Panel, 2014). Moreover, egg products (whole, yolk, or liquid egg white) are used in the fabrication of various foodstuffs (sausages, sauces, cakes, pasta, etc.) and it is clearly important that such egg products are pathogen-free, especially when preparation does not include cooking. However, the traditional heat treatment of liquid egg white (e.g., $57^{\circ} \mathrm{C}$ for just $2 \mathrm{~min}$ ) does not result in the total destruction of $S$. Enteritidis, although does preserve the techno-functional properties of egg white (Baron, 2010). The high occurrence of the $S$. Enteritidis in egg-related food-borne disease can also be explained by the specialized ability of this serovar to survive under the harsh conditions encountered in egg white (Lock and Board, 1992; Clavijo et al., 2006; Guan et al., 2006; Gantois et al., 2008b, 2009a), although the mechanisms associated with the exceptional egg white resistance exhibited by $S$. Enteritidis have yet to be entirely resolved.

Many studies have focused on identifying $S$. Enteritidis factors conferring resistance to egg white. Approaches employed include directed mutagenesis (Lu et al., 2003; Cogan et al., 2004; Kang et al., 2006), random mutagenesis (Clavijo et al., 2006), in vivo expression technology (IVET) (Gantois et al., 2008a) and microarray-based transposon library screening (Raspoet et al., 2014). Such studies have revealed genes essential for the survival of $S$. Enteritidis in egg white, including those with roles in membrane structure and function, the metabolism of nucleic acids and amino acids, motility, the synthesis and repair of DNA, invasion and pathogenicity. However, comparison between such studies is complicated by the wide range of experimental conditions and methods employed, such that the relative contributions of individual components remains uncertain. Nevertheless, it is generally accepted that the key antibacterial influences of egg white are iron deficiency (provoking bacteriostatisis) and bacterial-cell envelop damage (which is bactericidal) (Kang et al., 2006). However, physico-chemical factors, such as alkaline $\mathrm{pH}$ and temperature of incubation, also play important roles in egg white antimicrobial activity. Immediately after laying, the loss of carbon dioxide through the pores of the eggshell leads to a rapid increase in egg white $\mathrm{pH}$, from 7.8 to 9.3 over 4-14 days, depending on temperature (Sauveur, 1988). This increased alkalinity is important since, at $\mathrm{pH} \geq 8.8$, egg white displays bacteriostatic and/or bactericidal properties, whereas at $\mathrm{pH} 7.5$ or 8 either weak bacterial growth or a bacteriostatic activity are observed, respectively (Tranter and Board, 1984; Messens et al., 2004; Kang et al., 2006).

Temperature also has a major impact on $S$. Enteritidis growth in egg white. At 20 and $30^{\circ} \mathrm{C}$, many reports suggest that $S$. Enteritidis is able to grow slightly in egg white. The increase varies from one to four logarithmic units/mL depending on the authors and incubation time (Clay and Board, 1991; Lock and Board, 1992; Humphrey and Whitehead, 1993; Ruzicková, 1994; Baron et al., 1997; Chen et al., 2005; Murase et al., 2005). At $37^{\circ} \mathrm{C}$, the results observed by different authors vary: several report a maintenance or death of $S$. Enteritidis in egg white (Bradshaw et al., 1990; Ruzicková, 1994; Clavijo et al., 2006; Guan et al., 2006) whilst others indicate a slight growth (Kang et al., 2006). Kang et al. (2006) suggest that growth, maintenance or death of $S$. Enteritidis incubated at $37^{\circ} \mathrm{C}$ in egg white depends on the inoculum size. However at $42^{\circ} \mathrm{C}$, a bactericidal effect of egg white against $S$. Enteritidis is systematically observed, with destruction varying from $<2$ to 3.5 logarithmic units $/ \mathrm{mL}$, depending on incubation time and laboratory (Guan et al., 2006; Kang et al., 2006; Gantois et al., 2008a). The literature thus indicates that higher temperature and alkaline $\mathrm{pH}$ enhance the antibacterial activity of egg white. It is notable that temperatures that support the bactericidal activity of egg white are close to those encountered naturally during egg formation and that of the hen body $\left(42^{\circ} \mathrm{C}\right)$; this temperature is routinely used in studies on the bactericidal activity of egg white (Guan et al., 2006; De Vylder et al., 2013; Raspoet et al., 2014). Indeed, the relation with temperature and antimicrobial activity of egg white is underlined by a patent describing a novel egg white pasteurization process (Liot and Anza, 1996) involving incubation of liquid egg white at moderate temperatures (best results at $42-45^{\circ} \mathrm{C}$ ) for $1-5$ days. This method is considered superior to the less efficient, but more traditional, "egg white pasteurization" treatment (e.g., $57^{\circ} \mathrm{C}$ for $2-5 \mathrm{~min}$ ) since it provides a complete killing of $S$. Enteritidis, preserves the techno-functional properties of the egg white and allows subsequent storage of liquid egg white at room temperature rather than under refrigeration (Baron, 2010). Studying the global response of $S$. Enteritidis to egg white incubation at $42-45^{\circ} \mathrm{C}$ would provide insight into the killing mechanisms involved that might enable a further optimization of the control of this pathogen in eggs and egg products.

Recently, the contribution of temperature $\left(37-48^{\circ} \mathrm{C}\right), \mathrm{pH}$ (7.8 and 9.3), inoculum size (3-8 $\log _{10} \mathrm{CFU}$ ) and egg whiteprotein concentration (using egg white and egg white model medium) to the antimicrobial activity of egg white was more thoroughly investigated using factorial design analysis (Alabdeh et al., 2011). The results provided two major conclusions: firstly, that the key role played by egg white proteins in antimicrobial activity depends on both temperature and $\mathrm{pH}$; and secondly, that the bactericidal activity of egg white against $S$. Enteritidis 
only becomes apparent at $\geq 42^{\circ} \mathrm{C}$. These findings thus identify the conditions required for egg white dependent killing of $S$. Enteritidis allowing further research on the mechanisms involved. The study described here further addresses the bactericidal activity of egg white and the corresponding response of $S$. Enteritidis. We examine the global expression response of $S$. Enteritidis to egg white model medium exposure for $45 \mathrm{~min}$ at $45^{\circ} \mathrm{C}$ and $\mathrm{pH} 9.3$, and reveal major changes in transcription that correlate well with the conditions presented by egg white. The results provide novel insight into the environmental signals encountered by $S$. Enteritis in egg white and the expressionresponse that this pathogen displays in its attempt to adapt to such exposure.

\section{MATERIALS AND METHODS}

\section{Bacterial Strain}

Salmonella Enteritidis NCTC13349 was used in this study (kindly donated by Matthew McCusker, Center for Food Safety and Food Borne Zoonomics, Veterinary Sciences Centre, University College Dublin, Ireland). This strain was isolated from an outbreak of human food poisoning in the United Kingdom that was traced back to a poultry farm. The stock cultures were conserved at $-20^{\circ} \mathrm{C}$ with $50 \%(\mathrm{v} / \mathrm{v})$ glycerol. Before use, cells were propagated twice overnight at $37^{\circ} \mathrm{C}$ in tryptone soy broth (TSB, Merck, Darmstadt, Germany) without shaking.

\section{Preparation of Sterile Egg White and Egg White Model Medium}

Egg white was prepared from 5 to 10 day-old eggs obtained from conventional hen housing system. Eggshell surfaces were cleaned with tissue paper, checked for cracks and then sterilized with 70\% alcohol; residual alcohol was removed by briefly flaming the shell. Eggshells were then broken, under sterile conditions, and the released egg whites were aseptically homogenized with a DI25 Basic homogenizer (Ika, Grosseron, Saint-Herblain, France) at $9,500 \mathrm{rpm}$ for $1 \mathrm{~min}$. The egg white $\mathrm{pH}$ was $9.3 \pm 0.1$.

Egg white filtrate was prepared by ultrafiltration of three different batches of liquid egg white (from different eggs). Ultrafiltration was performed using a pilot unit (TIA, Bollène, France) equipped with an Osmonics membrane $\left(5.57 \mathrm{~m}^{2}, 10 \mathrm{kDa}\right.$ cut-off; PW 2520F, Lenntech B.V., Delft, Netherlands). Filtration was achieved according to Baron et al. (1997). Concentrated egg white (retentate) was circulated back to the feedtank and permeate (filtrate) was drained off, collected in a beaker, sterilized by filtration (Nalgene ${ }^{\circledR}$ filter unit, pore size $<0.2 \mu \mathrm{m}$, Osi, Elancourt, France), and then stored at $4^{\circ} \mathrm{C}$ until use. The $\mathrm{pH}(9.3$ \pm 0.1 ) of the egg white filtrate remained unchanged.

Egg white model medium (EWMM) was prepared by adding $10 \%$ egg white ( $\mathrm{vol} / \mathrm{vol})$ to egg white filtrate. The solution was then homogenized with a DI25 basic homogenizer at 9,500 rpm for $1 \mathrm{~min}$ following which the $\mathrm{pH}$ was re-confirmed $(9.3 \pm 0.1)$. Medium sterility was monitored by inoculating tryptone soy agar (TSA, Merck, Darmstadt, Germany) plates with $1 \mathrm{ml}$ of EWMM and then confirming lack of colony formation after overnight incubation at $37^{\circ} \mathrm{C}$. The egg white filtrate $\mathrm{pH}$ was $9.3 \pm 0.1$.

\section{Incubation of S. Enteritidis in Egg White or Egg White Model Medium}

After propagation in tryptone soy broth, bacterial suspensions were centrifuged at $5,600 \times \mathrm{g}$ and $15^{\circ} \mathrm{C}$ for $7 \mathrm{~min}$, and cells were washed three times with egg white filtrate. The final pellet was resuspended in the original volume of egg white filtrate and was then inoculated into egg white or in EWMM at a final concentration of $7.3 \pm 0.2 \log _{10} \mathrm{CFU} / \mathrm{ml}$. The resuspended bacteria were incubated at 30 or $45^{\circ} \mathrm{C}$ for 45 min and $24 \mathrm{~h}$ to evaluate the bactericidal activity of egg white and EWMM. Bacterial suspensions of $S$. Enteritidis (overnight cultures centrifuged at $5,600 \times \mathrm{g}$ and $15^{\circ} \mathrm{C}$ for $7 \mathrm{~min}$, and washed three times with fresh optimum medium, TSB) were also incubated in TSB at $\mathrm{pH} 7.3$ for $24 \mathrm{~h}$ at 30 and $45^{\circ} \mathrm{C}$, as a control.

For transcriptome analysis, bacterial suspensions of $S$. Enteritidis prepared as above were incubated in EWMM ( $7.3 \pm$ $0.2 \log _{10} \mathrm{CFU} / \mathrm{ml}$ in aliquots of $20 \mathrm{ml}$ ) for 7,25 , or $45 \mathrm{~min}$ at $45^{\circ} \mathrm{C}$ before RNA extraction.

\section{Numeration of Bacterial Cells after Incubation}

A numeration method based on miniaturization of the conventional plate-counting technique was used according to Baron et al. (2006) with a Tryptone soya agar (Merck, Darmstadt, Germany) overlay procedure. After incubation at $37^{\circ} \mathrm{C}$ for $20-24$ $\mathrm{h}$, the number of colony forming units (CFU) was recorded. Results were compared using analysis of variance and the average comparison test using the R 2.13.0 software (http://cran. r-project.org/).

\section{RNA Isolation and Synthesis of cDNA}

After incubation, cells were centrifuged at $10,000 \times \mathrm{g}$ at $4^{\circ} \mathrm{C}$ for $5 \mathrm{~min}$, pellets were immediately frozen in liquid nitrogen and stored at $-80^{\circ} \mathrm{C}$. After defrosting on ice, cells were disrupted by treatment with TE (10 mM Tris- $\mathrm{HCl} \mathrm{pH} 7,1 \mathrm{mM}$ EDTA) buffer, containing $20 \mathrm{mg} / \mathrm{mL}$ lysozyme, for $30 \mathrm{~min}$ at $37^{\circ} \mathrm{C}$ followed by mechanical lysis with zirconium beads using a FastPrep-24 instrument (MP Biomedicals, Illkirch, France) with two cycles of $30 \mathrm{~s}$ at $30 \mathrm{~Hz}$ interspaced with $30 \mathrm{~s}$ cooling periods. Total RNA was then isolated by phenol-chloroform extraction. The evaluation of RNA quantity and quality was assessed spectrophotometrically by measuring the ultraviolet absorbance profile (NanoDrop, NanoDrop Technologies, Inc., Rockland, Wilmington, DE, USA) at 230, 260, and $280 \mathrm{~nm}$. For the microarray experiment, additional analysis for RNA integrity was performed using a RNA 6000 Nano LabChip kit (2100 Bioanalyzer, Agilent Technologies, Santa Clara, CA, USA) (Mueller et al., 2000). The RNA samples were then DNase treated using a DNA-free kit (Ambion, Austin, TX, USA) according to the manufacturer's instructions. Quantification of the RNA and any contamination by proteins was again assessed using a NanoDrop ND-1000 and RNA integrity again confirmed using a 2100 Bioanalyzer. The resultant total RNA (500 ng of each sample) was reverse transcribed and labeled using the SuperScriptTM Indirect cDNA Labeling System (Invitrogen, Life Technologies, Courtaboeuf, France) according 
to the protocol provided by the manufacturer, except that the hexamer solution was replaced with the pdN6 hexamer solution (Roche Diagnostics, Meylan, France).

\section{Microarray and Experimental Design}

A DNA microarray was designed based on the only published genome sequence for Salmonella Enteritidis strain NCTC13349 (http://www.ncbi.nlm.nih.gov/nuccore/AM933172.1). The microarray, containing 3971 ORFs (representing $94.4 \%$ of $S$. Enteritidis gene composition), was designed using Agilent's e-array software (https://earray.chem.agilent.com/earray/). Note that 235 ORFs were not included due to restricted design parameters of the e-array program. The custom oligonucleotide microarray was manufactured by Agilent Technologies using an $8 \times 15 \mathrm{~K}$ format and included each probe in duplicate. Microarray hybridization and data analysis were performed by the Pasteur Institute (Transcriptome and Epigenome Platform PF2, Paris, France).

S. Enteritidis, exposed to egg white model medium for 7,25 , and $45 \mathrm{~min}$ at $45^{\circ} \mathrm{C}$, was compared to a reference control ( 0 min of incubation) consisting of $S$. Enteritidis grown overnight in $\mathrm{TSB}$ at $37^{\circ} \mathrm{C}$, washed three times in egg white filtrate and finally resuspended in egg white filtrate at ambient temperature. For each time point, three arrays were hybridized with three independent biological replicates in duplicate (giving three biological replicates and two technical replicates). Cy3 and Cy5 dye-swap design was included in order to reduce dyespecific effects. The data have been deposited in NCBI's Gene Expression Omnibus and are accessible through GEO Series accession number GSE92545 (http://www.ncbi.nlm.nih.gov/geo/ query/acc.cgi?acc=GSE92545).

\section{Data Acquisition and Preprocessing}

Images of the microarrays were scanned using an Axon 4000a scanner (Axon, Instruments, CA, USA) and intensity data were extracted using the GenepixPro 6.1 software. Raw microarray data were first normalized using the LOWESS (Locally Weighted Scatter Plot Smoother) regression option in the $\mathrm{R}$ software suite, version 2.10.1 (http://www.r-project.org/), to correct for dye-bias within the array, followed by median normalization to normalize across all arrays.

\section{Differential Expression Analysis}

Changes in gene expression upon incubation in EWMM compared to the control were recorded as fold changes (ratio of 7, 25, or 45-0 min). Statistical significance was estimated with a moderated t-test using the LIMMA package (Smyth, 2004) of the $\mathrm{R}$ software suite (version 2.10.1). The adjustment of raw $p$-values was then performed to account for multiple comparisons, using the method of Benjamini and Yekutieli (2001). Genes that exhibited $\geq 2.0$ fold changes in expression (with respect to the control) and $P \leq 0.05$ were considered as differentially regulated. Differentially expressed genes were initially categorized by function according to the Clusters of Orthologous Groups (http://www.ncbi.nlm.nih.gov/COG) designations and categorization was subsequently optimized manually.

\section{Confirmation of Selected Genes by qRT-PCR Analysis}

Confirmation of the transcriptomic analyses was achieved using qRT-PCR. Primers (Table 1) for amplification of selected genes were designed using Primer 3 (http://primer3.ut.ee/). Noncontamination of RNA by gDNA was confirmed by qPCR prior to cDNA synthesis. cDNA was synthesized using the high-capacity cDNA archieve kit (Applied Biosystems) as recommended by the manufacturer. qRT- PCR was performed using an iCycler iQ Real-Time PCR Detection System (Biorad). Thermal cycling consisted of $5 \mathrm{~min}$ at $95^{\circ} \mathrm{C}$, followed by 45 cycles of $15 \mathrm{~s}$ at $95^{\circ} \mathrm{C}, 20 \mathrm{~s}$ at $60^{\circ} \mathrm{C}$ and $40 \mathrm{~s}$ at $72^{\circ} \mathrm{C}$. A melting curve analysis $\left(55^{\circ} \mathrm{C}\right.$ to $\left.95^{\circ} \mathrm{C}\right)$ was performed after the thermal profile to ensure specificity and PCR efficiency was calculated at between 85 and $105 \%$ from the log-linear portion of the standard curves. A total of two RNA extractions were performed using distinct $S$. Enteritidis cultures grown on different batches of EWMM. Each of the two RNA extracts thus obtained was subject to qRTPCR, in triplicate, for each selected gene. Standard curves were generated to calculate the copy number of each gene in each sample. The most stable control genes in our conditions were determined by geNorm among five potential genes. qRT-PCR data were normalized by geometric averaging of three internal control genes (asmA, emrA, orf32; primers in Table 1). Gene expression is thus provided as relative expression with respect to the normalization factor calculated by geNorm.

\section{RESULTS}

\section{Egg White and Egg White Model Medium Exhibit Strong Bactericidal Activity at $45^{\circ} \mathrm{C}$, But Are Only Bacteriostatic at $30^{\circ} \mathrm{C}$}

In order to establish suitable conditions for investigating the impact of egg white bacteriocidal activity on $S$. Enteritidis global gene expression, the effects of egg white (EW) and egg white model medium (EWMM; egg white filtrate supplemented with $10 \%$ egg white) on growth and survival of $S$. Enteritidis after $24 \mathrm{~h}$ were examined at both 30 and $45^{\circ} \mathrm{C}$, at $\mathrm{pH} 9.3$ (which corresponds to the natural $\mathrm{pH}$ of egg white, as achieved a few days after laying). Pre-cultures in tryptone soya broth (TSB, $\mathrm{pH}$ 7.3) were washed (three times) in EW filtrate and inoculated into $\mathrm{EW}$ and EWMM to give $7.3 \pm 0.2 \log _{10} \mathrm{CFU} / \mathrm{ml}$. At $30^{\circ} \mathrm{C}$, there

TABLE 1 | Sequences of primers used for qPCR.

\begin{tabular}{lll}
\hline Gene & Forward primer & Reverse primer \\
\hline asmA & ACCGGACACGTTCAGGTAAC & GGCAACAGGTTGTCCAGATT \\
bioB & CCGAGCGTTAATGGAGGTA & TGACGCCCTGTACAATCTG \\
dgoK & TCTGATTGCCTGCTCTCCA & GCAATTGACTGGGGATCGAC \\
emrA & ATCTGTGGGTGGACGCTAAC & CCATATCCAGACCGACGACT \\
fes & CGCGTITGGCTGTGTACTA & TCAGCCGGGTAATGACTTC \\
ftn & GCCACATACCACTGCAAGAA & CGACCTATGAGCATGAGCAG \\
iroB & TTGTCGGTCCACCACTGTA & AGCGTCAAATACCACCAACC \\
orf32 & CGGCTCTTAACGCTCTGAC & CCGGTGGGTTTGATAAATG
\end{tabular}




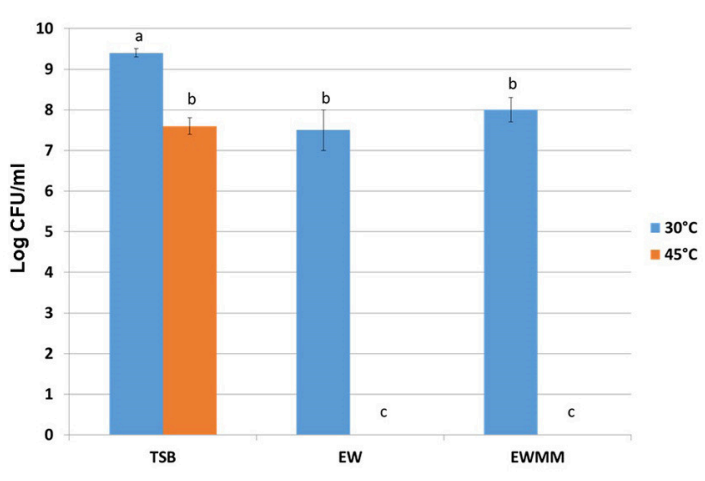

FIGURE 1 | S. Enteritidis survival after $24 \mathrm{~h}$ incubation at 30 or $45^{\circ} \mathrm{C}$ in optimum medium (TSB), egg white (EW) or in egg white model medium (EWMM). Inoculum levels were $7.3 \pm 0.2 \log _{10} \mathrm{CFU} / \mathrm{ml}$. Experiments were performed in triplicate. Samples with different letters are significantly different $(p<0.05)$.

was only slight growth (increases of $\sim 0.2$ and $0.7 \log _{10} \mathrm{CFU} / \mathrm{ml}$, respectively) whereas when a rich (TSB) medium was employed good growth (increase of $2.1 \log _{10} \mathrm{CFU} / \mathrm{ml}$ ) was achieved after 24 $\mathrm{h}$ at $30^{\circ} \mathrm{C}$ (Figure 1). These observations confirm that both EW and EWMM impose a bacteriostatic influence on $S$. Enteritidis at $30^{\circ} \mathrm{C}$ (Baron et al., 1997). In contrast, after incubation at $45^{\circ} \mathrm{C}$ for $24 \mathrm{~h}$ (Figure 1), S. Enteritidis was undetectable in either EW or EWMM (indicating a reduction of $7.3 \log _{10} \mathrm{CFU} / \mathrm{ml}$ ), while in TSB at $45^{\circ} \mathrm{C}$ slight growth was observed (increase of $0.3 \log _{10}$ $\mathrm{CFU} / \mathrm{ml}$ ). Thus, EW and EWMM both exhibit strong bactericidal activity at $45^{\circ} \mathrm{C}$, but are only bacteriostatic at $30^{\circ} \mathrm{C}$. The similarity between the effects of EW and EWMM, as observed above, were previously described (Baron et al., 1997; Alabdeh et al., 2011) and validate the use of EWMM in place of EW in the gene expression studies described below. The use of EWMM in place of EW was necessary in order to enable easy recovery of $S$. Enteritidis following exposure to EWMM, which is not possible with EW due to its highly viscous consistency.

\section{Egg White Exposure Induces Major Changes in the S. Enteritidis Transcriptome}

The above data show that EWMM elicites $S$. Enteritidis cell death at $45^{\circ} \mathrm{C}$. Thus, incubation at $45^{\circ} \mathrm{C}$ in EWMM represents suitable conditions for examination of the response of $S$. Enteritidis to the bactericidal activity of EW using a global-expression analysis approach. For this purpose, relatively short incubation times (7, 25 , and $45 \mathrm{~min}$ ) were selected, where no major reduction in viable cell number occurred (observed change was from $7.3 \pm$ $0.2 \log _{10}$ to $7.1 \pm 0.3 \log _{10} \mathrm{CFU} / \mathrm{ml}$ at $0-45 \mathrm{~min}$, respectively), which corresponds to the early phase of EWMM-induced lethalcell damage. It should be noted that continued exposure resulted in progressive cell death (at a rate of $\sim 1 \log _{10} \mathrm{CFU} / \mathrm{ml}$ every $3 \mathrm{~h}$; data not shown) leading to no detectable cells after 24 $\mathrm{h}$ of incubation (Figure 1). Expression effects were determined using a Salmonella microarray representing $94.4 \%$ of the genome ( $\sim 3,971$ genes). For each incubation time in EWMM, expression was compared to that of the control $(t=0: S$. Enteritidis grown overnight at $37^{\circ} \mathrm{C}$ in TSB and then washed three times in egg white filtrate). Genes with a statistically significant $\geq$ twofold change in expression $(P \leq 0.05)$ were considered as differentially regulated. Thus, at 7, 25, and $45 \mathrm{~min}, 13.4 \%$ (288 induced and 277 repressed), $15.3 \%$ (304 induced and 362 repressed) and $18.7 \%$ (318 induced and 468 repressed) of genes were differentially regulated, respectively. This indicates that a high proportion of the genome was subject to expression alteration and that there was an increasing degree of change with time upon exposure to EWMM at $45^{\circ} \mathrm{C}$. Examination of the expression data showed that the differentially-regulated genes can be classified into 11 major functional groups (Tables 2-11), and that these can be further organized into three broad functional categories: nutrient deprivation; cell damage/stress; and shift in energy metabolism and catabolism.

\section{Nutrient Deprivation}

\section{Induction of Genes Involved in Biotin Biosynthesis}

The genes of the bioABCDF operon, encoding the biotin biosynthesis components, were strongly up-regulated following 7-45 min exposure to EWMM at $45^{\circ} \mathrm{C}$; expression was between 6.75- and 25.41-fold increased at $45 \mathrm{~min}$ (Table 2). This induction matches the poor biotin availability in egg white resulting from the presence of avidin, a powerful biotin-chelation protein (Banks et al., 1986), There was also a 4.75- to 5.81fold increase in expression of the biotin-related $a c c B C$ operon at $45 \mathrm{~min}$. The $a c c B$ gene encodes the Biotin Carboxyl Carrier Protein which is the direct recipient of biotin following synthesis and forms part of acetyl-CoA carboxylase that catalyzes the first step in fatty acid biosynthesis (Cronan, 1996; Streit and Entcheva, 2003; Beckett, 2007). Coordinated induction of $a c c B C$ is necessary for stimulation of the synthesis of biotin (AbdelHamid and Cronan, 2007).

\section{Induction of Genes Involved in Iron-Restriction Response}

A substantial expression effect was observed for genes involved in the response to iron starvation, with 49 genes in this functional category exhibiting significant expression changes. The overall differential expression of iron-starvation genes steadily increased over the time period of egg white exposure (0-45 min, Table 3), suggesting a sustained iron-restriction effect over this time. Under iron restriction, bacteria typically synthesize and secrete high-affinity ferric chelators, called siderophores, which solubilize exogenous iron, making it available for uptake (Neilands, 1995). Salmonella produces two types of cathecholate siderophore, enterobactin and salmochelin, but it can also pirate hydroxamate siderophores generated by competing microbes. The uptake of ferri-siderophore complexes involves specific outer-membrane $(\mathrm{OM})$ receptors, an OM energy-transducing system and a periplasmic-binding protein dependent ATPbinding cassette inner-membrane permease (Andrews et al., 2003). The ferric uptake regulator (Fur) acts as the master regulator of iron homeostasis in the Enterobacteriaceae, controlling the iron-uptake machinery according to iron regime.

Exposure of Salmonella to EWMM at $45^{\circ} \mathrm{C}$ stimulated a strong expression of the entABCDEFHS gene cluster (4.13- to 
TABLE 2 | Biotin biosynthesis and utilization.

\begin{tabular}{|c|c|c|c|c|}
\hline \multirow[t]{2}{*}{ Gene } & \multirow[t]{2}{*}{ Function } & \multicolumn{3}{|c|}{ Fold change } \\
\hline & & $7 \mathrm{~min}$ & $25 \mathrm{~min}$ & $45 \mathrm{~min}$ \\
\hline \multicolumn{5}{|c|}{ BIOTIN BIOSYNTHESIS } \\
\hline bioA & Adenosylmethionine-8-amino-7-oxononanoate transaminase & 4.32 & 6.01 & 6.65 \\
\hline bioB & Biotin synthetase & 12.31 & 19.50 & 23.39 \\
\hline bioc & Biotin biosynthesis protein BioC & 5.89 & 13.22 & 16.55 \\
\hline bioD & Dithiobiotin synthetase & 6.51 & 14.23 & 19.76 \\
\hline biof & 8-amino-7-oxononanoate synthase & 9.75 & 19.11 & 25.41 \\
\hline \multicolumn{5}{|c|}{ FATTY ACID METABOLISM } \\
\hline accB & Acetyl-CoA carboxylase biotin carboxyl carrier protein subunit & n.s. & 3.31 & 4.75 \\
\hline accC & Acetyl-CoA carboxylase biotin carboxylase subunit & n.s. & 3.43 & 5.81 \\
\hline
\end{tabular}

Highlighted fold changes correspond to up-regulated (dark gray) and down-regulated (light gray) genes. (n.s., non-significant), fold changes with $p>0.05$.

7.81-fold at $45 \mathrm{~min}$ ) which encodes the proteins involved in biosynthesis and export of enterobactin, the major siderophore of Salmonella. The genes involved in ferric-enterobactin uptake and utilization ( $f e p A B C D G$, fes, and $\operatorname{cir} A$ ) were likewise strongly induced (4.01- to 7.18-fold at $45 \mathrm{~min}$ ) as were the genes involved in ferric-hydroxamate uptake ( $f h u A B C D$ and fhuE, 1.77 to 4.57 fold at $45 \mathrm{~min}$ ) and ferric-hydroxamate utilization ( $f h u F$, tenfold at $45 \mathrm{~min}$ ). The iro genes, required for conversion of enterobactin to salmochelin as well as uptake and utilization of ferricsalmochelin, were also significantly induced (1.59- to 4.11-fold at $45 \mathrm{~min}$ ) but to a lesser extent than the afore mentioned ironuptake genes. The energy-transducing TonB-ExbB-ExbD system was also up-regulated (2.77- to 4.95 -fold at $45 \mathrm{~min}$ ). The Fe-Fur induced $f t n A$ gene (encoding ferritin $\mathrm{A}$, an iron-storage protein) was suitably repressed, an effect that increased from 7 to $45 \mathrm{~min}$ (0.19-fold at $45 \mathrm{~min}$ ).

All the above genes are Fe-Fur regulated (Bjarnason et al., 2003; McHugh et al., 2003). The combined induction of the ironacquisition genes and repression of the iron-storage gene strongly suggest that exposure of Salmonella to EWMM induces a FeFur controlled homeostatic reaction in response to the prevailing iron-restriction conditions of the medium.

The Fur-mediated response of Salmonella was not limited to adjustment in iron uptake and storage capacity. The FeFur repressed sufABCDS operon, encoding an alternative Fe$S$ cluster biosynthetic pathway employed during redox stress and iron starvation in E. coli (Outten et al., 2004), was also induced (3.77- to 9.35 -fold at $45 \mathrm{~min}$ ). In addition, the nrdHIEF genes specifying an alternative, Fe-Fur repressed, Mndependent ribonucleotide reductase (Martin and Imlay, 2011), were induced 5.18- to 15.4 -fold at $45 \mathrm{~min}$. The expression of the $\operatorname{sod} A$ and $\operatorname{sod} B$ genes, involved in the response to superoxide (redox-cycling agents) stress, was also significantly affected by EWMM exposure. SodA is a Mn-dependent superoxide dismutase whereas SodB is Fe-dependent. Both are Fe-Fur controlled, but in a reciprocal fashion-sodA is Fe-Fur repressed whilst $\operatorname{sodB}$ is Fe-Fur (via RfrA and RfrB) induced (Troxell et al., 2011). Upon exposure to EWMM, $\operatorname{sod} A$ was induced (3.05-fold at $45 \mathrm{~min})$ and $\operatorname{sod} B$ was repressed (0.14-fold at $45 \mathrm{~min})$. A similar pattern of expression was observed by Dubrac and Touati $(2000,2002)$ and McHugh et al. (2003).

The sit $A B C D$ operon, encoding a manganese-uptake system active in alkaline conditions (Kehres et al., 2002), was also induced (4.71- to 9.54-fold at $45 \mathrm{~min}$ ) in EWMM. This system is known to be induced by low iron in response to Fur, but also by low $\mathrm{Mn}^{2+}$ in response to MntR (Ikeda et al., 2005). It has the capacity to import ferrous iron, but has strong preference for $\mathrm{Mn}^{2+}$ over $\mathrm{Fe}^{2+}$ (Kehres et al., 2002). $\mathrm{Mn}^{2+}$ uptake in $E$. coli only occurs when iron is depleted, probably to prevent interference of $\mathrm{Mn}^{2+}$ with cellular iron distribution (Anjem et al., 2009; Andrews, 2011). A similar effect would be anticipated for Salmonella. The Fur- and MntR-controlled $m n t H$ gene, also involved in $\mathrm{Mn}^{2+}$ and $\mathrm{Fe}^{2+}$ uptake (with a preference for $\mathrm{Mn}^{2+}$ ), was also induced but in lesser extent (up to 2.1 -fold at $45 \mathrm{~min}$ ). The greater induction response of sitABCD than that of $m n t H$ may be related to the distinct $\mathrm{pH}$ preferences of their encoded products; $\mathrm{MntH}$ exhibits optimal $\mathrm{Mn}^{2+}$ transport under acidic conditions whereas SitABCD has preference for alkaline $\mathrm{pH}$ (Kehres et al., 2002).

The $y d i E$ gene was also induced by EWMM. This gene encodes a protein of unclear function and is related to the hemeutilization component, HemP of Yersinia enterolitica (Stojiljkovic and Hantke, 1992; Panina et al., 2001). The ydiE gene is Fe-Fur repressed in S. Typhimurium (Lutz and Bujard, 1997; Bjarnason et al., 2003), and its induction in EWMM is consistent with FeFur repression in $S$. Enteritidis. The Fe-Fur repressed $y q j H$ and bfd genes are considered to be involved in iron mobilization (Miethke et al., 2011; Yao et al., 2012). Appropriately, both were induced by EWMM (Table 3). Interestingly, there was no significant change in the expression of the feo $A B C$ operon, encoding the anaerobic, high-affinity ferrous-iron transporter. This may reflect the requirement for anoxic conditions for strong feo induction (Kammler et al., 1993).

In summary, the microarray data indicate a major ironstarvation response for $S$. Enteritidis.

\section{Repression of Genes Involved in Virulence}

Fifteen genes among the $\sim 30$ genes located within Salmonella Pathogenicity Island 1 (SPI1) were significantly down regulated 
TABLE 3 | Iron starvation genes.

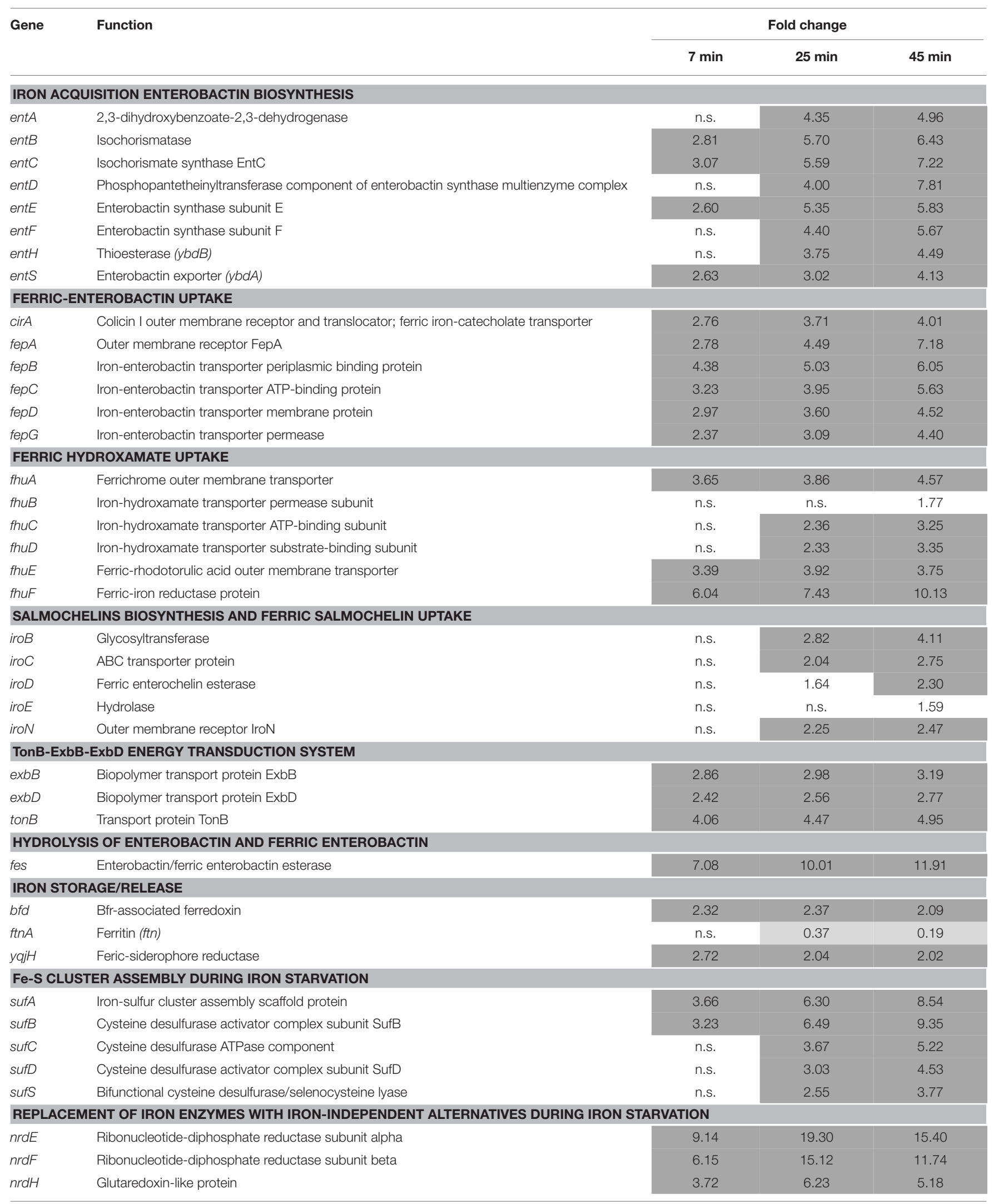




\section{TABLE 3 | Continued}

\begin{tabular}{|c|c|c|c|c|}
\hline Gene & Function & \multicolumn{3}{|c|}{ Fold change } \\
\hline sodA & Superoxide dismutase & 2.53 & 3.48 & 3.05 \\
\hline $\operatorname{sod} B$ & Superoxide dismutase & 0.39 & 0.23 & 0.14 \\
\hline \multicolumn{5}{|c|}{ MANGANESE UPTAKE } \\
\hline sitA & Fe/Mn transport protein, periplasmic-binding protein & 5.31 & 7.19 & 9.54 \\
\hline sitB & $\mathrm{Fe} / \mathrm{Mn}$ transport protein, ATP-binding component & 4.32 & 6.03 & 8.51 \\
\hline sitc & $\mathrm{Fe} / \mathrm{Mn}$ transport protein, inner membrane component & 3.42 & 4.94 & 6.93 \\
\hline sitD & Fe/Mn transport protein, inner membrane component & 2.27 & 3.47 & 4.71 \\
\hline \multicolumn{5}{|c|}{ IRON UPTAKE FROM HEME } \\
\hline
\end{tabular}

Highlighted fold changes correspond to up-regulated (dark gray) and down-regulated (light gray) genes. (n.s.), fold changes with p $>0.05$.

during the 45 min exposure to EWMM at $45^{\circ} \mathrm{C}$ (from 0.07 - to 0.48 -fold at 45 min; Table 4). SPI1 encodes a type III secretion system (T3SS) required for invasion of host gut epithelial cells in the early stages of infection. SPI1 expression is modulated by several environmental signals (Jones, 2005), which ensures its availability for invasion of epithelial cells when Salmonella reaches the distal small intestine. SPI1 is induced by iron in a Fur-dependent fashion (Teixidó et al., 2011) suggesting that the down regulation of the SPI1 genes observed here is due to the low iron concentration of egg white and consequent regulation change mediated by Fur.

\section{Cell Damage/Stress}

\section{Induction of Genes Involved in the Envelope-Stress Response, Mediated by CpxAR, OmpR/EnvZ and PspF Regulators}

A strong up-regulation of genes specifying proteins involved in various aspects of cell-envelop integrity was observed (Table 5). The induction of the spy gene increased with time of incubation giving a 22.18 -fold increase at $45 \mathrm{~min}$. The spy gene encodes a periplasmic chaperone protein that is induced by spheroplast formation, indole or zinc exposure as well as by misfolded envelope proteins (Hagenmaier et al., 1997; Yamamoto et al., 2008). Its expression is regulated by the two components systems, BaeSR and CpxAR (Raffa and Raivio, 2002), that mediate response to a variety of environmental stresses including suboptimal $\mathrm{pH}$ and factors perturbing the bacterial envelope (Raivio et al., 2013). Another CpxAR-regulated gene, htrA (degP), was also strongly induced (7.79-fold at $45 \mathrm{~min}) \cdot \operatorname{deg} P$ encodes a periplasmic, membrane-associated serine endoprotease that degrades abnormal proteins in the periplasm, preventing buildup of aggregated proteins.

The tolABQR and $y b g C$ genes were also induced, but to lesser extents (2.15- to 3.80-fold at $45 \mathrm{~min}$ ). These genes encode components of the YbgC-YbgF-TolQ-R-A-B-Pal Cell Envelope Complex, also known as the Tol-Pal system (although $y b g F$ and pal were not significantly induced). The genes of the Tol-Pal system are, like degP and spy, CpxAR induced (Bury-Moné et al.,
2009). The Tol-Pal system has a role in the maintenance of cellenvelope integrity (Lazzaroni et al., 1999; Cascales et al., 2000) and mutants (tolA or pal) exhibit an extra-cytoplasmic stress response characterized by a dramatic increase in the transcription of htrA (Vines et al., 2005). Two other CpxAR-regulated genes $(y n c J$ and $y j f N$ ), encoding envelope proteins, were also induced in EWMM at $45^{\circ} \mathrm{C}$ (Table 5) and these may play roles associated with membrane integrity (Raivio et al., 2013).

An induction of genes involved in cell permeability was also apparent with several porin-encoding genes exhibiting differential expression in response to EWMM exposure: ompC, ompX and ompS were up-regulated (2.53-, 2.19-, and 2.11fold, respectively, at $45 \mathrm{~min}$; Table 5); whereas $o m p F$ and $n m p C$ (named also ompD, the major porin of Salmonella) were downregulated (0.33- and 0.32-fold, respectively, at $45 \mathrm{~min}$; Table 5). Porins enable the diffusion of solutes through the OM and their regulation is controlled through their association with distinct sets of regulons (e.g., CpxAR, RpoE/ $\sigma^{\mathrm{E}}$, and OmpR/EnvZ) in response to a wide variety of environmental conditions such as $\mathrm{pH}$, osmolarity, temperature, toxins and growth phase (Pratt and Silhavy, 1996; Table 5). The expression effects observed here are consistent with CpxAR control either by direct CpxAR-mediated up- and down-regulation of $o m p C$ and $o m p F$, respectively, or by indirect control through other transcription factors such as OmpR/EnvZ (Batchelor et al., 2005; Dorel et al., 2006; Lin et al., 2012).

The CpxAR- and BaeSR-controlled acrD gene was induced (3.60-fold at $45 \mathrm{~min}$ ) in EWMM (Table 5). This gene specifies a multidrug-efflux system that removes antimicrobial compounds (e.g., aminoglycosides) from the bacterial cell. In contrast, the $m d t A B C$ operon specifying another drug-efflux pump that is also controlled by CpxAR and BaeSR, was not affected. This observation is consistent with previous studies showing increased expression of $a c r D$, but not $m d t A B C D$, under conditions that activated CpxAR but not BaeSR (Rosenberg et al., 2000; Price and Raivio, 2009). This suggests that the acrD induction seen here is CpxAR, not BaeSR, dependent. The emrD gene also encodes a multidrug efflux pump that was induced in EWMM (3.34-fold 
TABLE 4 | SPI1 genes.

\begin{tabular}{|c|c|c|c|c|}
\hline \multirow[t]{2}{*}{ Gene } & \multirow[t]{2}{*}{ Function } & \multicolumn{3}{|c|}{ Fold change } \\
\hline & & $7 \mathrm{~min}$ & $25 \mathrm{~min}$ & $45 \mathrm{~min}$ \\
\hline hilD & $\begin{array}{l}\text { AraC-family transcriptional } \\
\text { regulator (SPI1) }\end{array}$ & 0.36 & 0.20 & 0.16 \\
\hline invA & $\begin{array}{l}\text { EscV/YscV/HrcV family type } \\
\text { III secretion system export } \\
\text { apparatus protein }\end{array}$ & 0.34 & 0.25 & 0.17 \\
\hline $\operatorname{inv} B$ & $\begin{array}{l}\text { Surface presentation of } \\
\text { antigens protein SpaK }\end{array}$ & n.s. & 0.37 & 0.26 \\
\hline invE & Cell invasion protein (SPI1) & 0.23 & 0.19 & 0.18 \\
\hline $\operatorname{invG}$ & $\begin{array}{l}\text { Secretin EscC/YscC/HrcC } \\
\text { family type III secretion } \\
\text { system outer membrane } \\
\text { ring }\end{array}$ & 0.28 & 0.22 & 0.21 \\
\hline $\mathrm{invH}$ & Invasion lipoprotein InvH & 0.12 & 0.07 & 0.07 \\
\hline invl & $\begin{array}{l}\text { Surface presentation of } \\
\text { antigens protein SpaM }\end{array}$ & n.s. & n.s. & 0.30 \\
\hline $\operatorname{org} A$ & $\begin{array}{l}\text { Oxygen-regulated invasion } \\
\text { protein OrgB }\end{array}$ & n.s. & 0.30 & 0.23 \\
\hline $\mathrm{prgH}$ & $\begin{array}{l}\text { Pathogenicity } 1 \text { island } \\
\text { effector protein (SPI1) }\end{array}$ & 0.30 & 0.22 & 0.19 \\
\hline prgl & $\begin{array}{l}\text { EscF/YscF/HrpA family type } \\
\text { III secretion system needle } \\
\text { major subunit }\end{array}$ & 0.32 & 0.24 & 0.19 \\
\hline prgK & $\begin{array}{l}\text { EscJ/YscJ/HrcJ family type } \\
\text { III secretion inner membrane } \\
\text { ring protein }\end{array}$ & 0.50 & 0.39 & 0.27 \\
\hline $\operatorname{sic} A$ & $\begin{array}{l}\text { CesD/SycD/LcrH family } \\
\text { type III secretion system } \\
\text { chaperone }\end{array}$ & n.s. & n.s. & 0.28 \\
\hline $\operatorname{sip} B$ & Cell invasion protein SipB & 0.67 & n.s. & 0.48 \\
\hline spaP & $\begin{array}{l}\text { EscR/YscR/HrcR family } \\
\text { type III secretion system } \\
\text { export apparatus protein }\end{array}$ & 0.63 & 0.55 & 0.46 \\
\hline sprB & Transcriptional regulator & 0.46 & 0.31 & 0.25 \\
\hline
\end{tabular}

Highlighted fold changes correspond to up-regulated (dark gray) and down-regulated (light gray) genes. (n.s.), fold changes with $p>0.05$.

at $45 \mathrm{~min}$, Table 5). This gene may be involved in adaptation to energy-shock induced by exposure to uncouplers of oxidative phosphorylation (Naroditskaya et al., 1993).

Seven genes encoding peptidoglycan hydrolases involved in metabolism and turn-over of cell-wall peptidoglycan were also induced. These include the $\operatorname{dacC}$ and $\mathrm{dacD}$, encoding the DD-carboxypeptidases PBP6 and PBP6b, and amiC encoding a MurNAc-L-Ala amidase (Table 5). The mltA, mltD, emtA, and $y f h D$ genes encoding lytic endotransglycosylases were also induced. The amiC and $\mathrm{dacC}$ genes are positively regulated by CpxAR and it is suggested that their up-regulation induces a remodeling of the peptidoglycan in response to environmental challenge (Weatherspoon-Griffin et al., 2011; Raivio et al., 2013).

The pspADEG genes were also induced in EWMM with the strongest induction observed at $7 \mathrm{~min}$ and weakest at $45 \mathrm{~min}$ (Table 5). These are "phage-shock protein" genes ( $p$ s $A B C D E F G)$ that are induced in response to various membrane-altering stresses and are required for survival at high
$\mathrm{pH}$ (in E. coli; Weiner and Model, 1994). It is suggested that dissipation of the proton-motive force (pmf) acts as the inducing signal for psp expression (Darwin, 2005; Jovanovic et al., 2006).

In summary, the above indicate a major induction of membrane-stress related genes in cells exposed to EWMM at $45^{\circ} \mathrm{C}$. This effect is consistent with significant CpxAR- and PspFdependent gene activation.

\section{Induction of Genes Related to the Heat-Shock Response}

Incubation of $S$. Enteritidis in EWMM at $45^{\circ} \mathrm{C}$ caused up regulation of genes (groEL, groES, grpE, SEN1800 and $h t p G$ ) encoding heat-shock proteins (3.32- to 16.68-fold induced at 45 min, Table 6). The time-dependent expression data indicate that maximum expression was achieved rapidly (at 7-25 $\mathrm{min}$ ), following which expression declined (at $45 \mathrm{~min}$ ). This pattern is distinct from that seen for most of the other groups of differentially regulated genes highlighted here, but has been observed previously, in E. coli, in response to sudden temperature up-shift $\left(30-42^{\circ} \mathrm{C}\right.$ ) (Arsène et al., 2000; Guisbert et al., 2008) where it is considered to reflect the need for a rapid adaptation to temperature up-shift. Heat-shock expression is largely controlled by the alternative sigma factor, $\mathrm{RpoH}$, and provides protection against heat by stabilizing stress-denatured proteins (Rouvière et al., 1995).

\section{Induction of Genes Involved in a Translation Stress Response}

The relBE genes, encoding the RelE cytotoxin and RelB antitoxin, were induced in EWMM (3.47- and 3.26-fold for relE and $\mathrm{relB}$, respectively, at $45 \mathrm{~min}$ ). Overexpression of RelE is known to inhibit translation and cell growth (Gerdes et al., 2005). The RelBE system is thought to act as a ppGpp-independent stress-response regulator that blocks translation during aminoacid starvation or nutritional stress (Christensen et al., 2001). In addition, four genes encoding ribosome-binding proteins that also shutdown translation (Starosta et al., 2014) under conditions of stress (stationary-phase, cold shock or low energy status) were likewise induced: RaiA (pY, YfiA), the ribosomeassociated inhibitor A (raiA, 1.91 fold at $45 \mathrm{~min}$ ); RMF, the ribosome-modulation factor ( $r m f$, 5.76- fold at $45 \mathrm{~min}$ ); EttA $(\mathrm{YjjK})$, the "energy-dependent translational throttle A" (ettA, 2.13- fold at $45 \mathrm{~min}$ ); and SRA (RpsV, S22), the stationaryphase-induced ribosome-associated protein $(r s p V, 4.63$-fold at 45 min). These observations suggest that EWMM exposure induces a translational shutdown.

\section{Repression of Genes Involved in Amino Acid Biosynthesis and Uptake}

Genes involved in the synthesis and transport of amino acids were generally repressed by exposure of $S$. Enteritidis to EWMM at $45^{\circ} \mathrm{C}$ (Table 7). The amino acids affected include the branched chain group (Val, Leu and Ile), aromatic amino acids (tryptophan, phenylalanine, and tyrosine), threonine, arginine, cysteine, and asparagine.

In contrast to the general trend, $l y s C$ was up-regulated (5.99fold change at $45 \mathrm{~min}$ ). Consistent with this induction, lys $C$ is 
TABLE 5 | Membrane-stress related gene.

\begin{tabular}{|c|c|c|c|c|c|}
\hline \multirow[t]{2}{*}{ Gene } & \multirow[t]{2}{*}{ Function } & \multicolumn{4}{|c|}{ Fold change } \\
\hline & & $7 \mathrm{~min}$ & $25 \mathrm{~min}$ & $45 \mathrm{~min}$ & Control by \\
\hline \multicolumn{6}{|c|}{ CELL INTEGRITY } \\
\hline htrA (degP) & htrA; membrane-associated serine endoprotease, periplasmic & 4.83 & 8.32 & 7.79 & CpxAR $[2,9,13,18]$ \\
\hline spy & Spheroplast protein Y, periplasmic & 7.62 & 12.53 & 22.18 & CpxAR, BaeSR $[3,4,9,11,12,18,19]$ \\
\hline tolA & Tolerance to colicins and phage; cell envelope integrity; & 1.59 & 1.97 & 2.53 & CpxAR [12], PspF [12] \\
\hline tolB & Tolerance to colicins and phage; cell envelope integrity; & 1.76 & 1.89 & 2.15 & CpxAR[12], PspF [12] \\
\hline to/Q & Tolerance to colicins and phage; cell envelope integrity & 2.41 & 3.07 & 3.80 & CpxAR[12] \\
\hline tolR & Tolerance to colicins and phage; cell envelope integrity & 2.30 & 2.86 & 3.62 & \\
\hline$y b g C$ & Acyl-CoA thioester-hydrolase & 2.27 & 2.68 & 3.31 & CpxAR[12] \\
\hline yncJ & Secreted hypothetical protein & 6.35 & 14.31 & 19.35 & CpxAR [18] \\
\hline yjfN & Secreted hypothetical protein & n.s. & 3.04 & 3.79 & CpxAR $[4,18]$ \\
\hline \multicolumn{6}{|c|}{ CELL PERMEABILITY } \\
\hline$n m p C(o m p D)$ & Outer membrane porin protein & n.s. & 0.38 & 0.32 & CpxR $[15,18]$ \\
\hline ompC & Outer membrane porin protein $\mathrm{C}$ & 3.55 & 3.94 & 2.53 & CpxAR $[4,6,9,13,18]$, EnvZ/OmpR [10] \\
\hline ompF & Outer membrane protein F prcursor & n.s. & n.s. & 0.33 & CpxAR $[4,6,9,13,18]$, EnvZ/OmpR [10] \\
\hline omps & Outer membrane protein S1 & n.s. & 2.20 & 2.11 & EnvZ/OmpR [17] \\
\hline ompX & Outer membrane protein $X$ & n.s. & 2.27 & 2.19 & EnvZ/OmpR [17] \\
\hline \multicolumn{6}{|c|}{ MULTIDRUG EFFLUX SYSTEM } \\
\hline acrD & Aminoglycoside/multidrug efflux system & 1.96 & 2.42 & 3.60 & CpxR, BaeSR $[8,9,13,14,18]$ \\
\hline emrD & Multidrug resistance protein D & 1.98 & 2.47 & 3.34 & EnvZ /OmpR [5] \\
\hline \multicolumn{6}{|c|}{ PEPTIDOGLYCAN METABOLISM } \\
\hline amic & $\mathrm{N}$-acetylmuramoyl-L-alanine amidase & 2.74 & 2.87 & 3.05 & CpxAR $[13,16]$ \\
\hline dacC & D-alanyl-D-alanine carboxypeptidase & 3.84 & 3.77 & 3.21 & CpxAR [18] \\
\hline$d a c D$ & D-alanyl-D-alanine carboxypeptidase & 3.78 & 3.71 & 3.45 & \\
\hline emtA & Murein transglycosylase E & 2.04 & 1.52 & 1.41 & \\
\hline mitA & Murein transglycosylase A & 2.18 & 2.15 & 2.12 & \\
\hline$m / t D$ & Murein transglycosylase D & n.s. & 1.53 & 2.10 & \\
\hline$y f h D$ & Lytic transglycosylase F & n.s. & 1.61 & 2.10 & \\
\hline \multicolumn{6}{|c|}{ PROTON-MOTIVE FORCE DISSIPATION } \\
\hline$p s p A$ & Phage shock protein A & 4.08 & 2.84 & 2.42 & PspF $[1,7]$ \\
\hline$p s p D$ & Phage shock protein D & 2.88 & 1.86 & n.s. & PspF $[1,7]$ \\
\hline$p s p E$ & Thiosulfate sulfurtransferase PspE & 2.36 & 1.62 & n.s. & PspF $[1,7]$ \\
\hline pspG & Phage shock protein G & 4.08 & 2.75 & 2.38 & PspF $[1,7,12]$ \\
\hline
\end{tabular}

Highlighted fold changes correspond to up-regulated (dark gray) and down-regulated (light gray) genes. ( $n . s$.), fold changes with $p>0.05$.

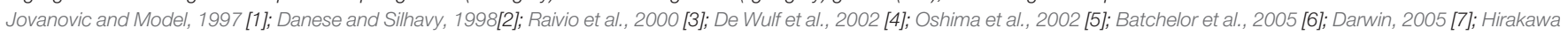

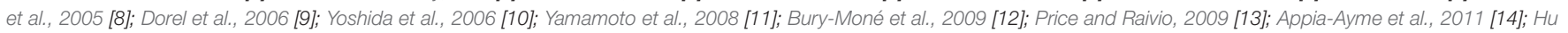
et al., 2011 [15]; Weatherspoon-Griffin et al., 2011 [16]; Perkins et al., 2013 [17]; Raivio et al., 2013 [18]; Rosner and Martin, 2013 [19].

reported to be required for viability in egg white at $37^{\circ} \mathrm{C}$ (Clavijo et al., 2006). lys $C$ encodes aspartate kinase involved in lysine, threonine and methionine biosynthesis and in the initial step of diaminopimelate (DAP) synthesis, required for peptidoglycan production (Rodionov, 2003). However, lysA, required for the final step of lysine synthesis, was down-regulated (0.10-fold change at $45 \mathrm{~min}$ ). It is possible that the increased expression of $l y s C$ reflects the need to regenerate peptidoglycan, which may also explain the slight induction of the $\operatorname{dap} A B D E$ genes (n.s. to 1.81 -fold at 45 min data not shown).

The oppABC operon, encoding an oligopeptide permease, and $A p p A B C D F$, specifying a dipeptide permease, were both down-regulated in EWMM (Table 7). These ABC transporters constitute a major route for peptide uptake (Hosie and Poole,
2001; Davidson and Chen, 2004). Their expression is expected to be dependent upon the availability of amino acids and need for protein synthesis (Sharma et al., 2007).

\section{Repression of Genes Involved in Motility and Chemotaxis}

Twenty eight genes involved in motility and chemotaxis were down-regulated (0.05- to 0.42 -fold at $45 \mathrm{~min}$, Table 8) with the degree of repression increasing over time. A strong repression was seen for the $f l h C D$ operon, the class I master operon that encodes the FlhCD regulatory complex. This complex is the principal regulator of bacterial flagellum biogenesis and swarming migration (Claret and Hughes, 2002). The class II FlhDC_regulated genes, which encode the flagella basal 
TABLE 6 | Temperature-related genes.

\begin{tabular}{|c|c|c|c|c|}
\hline \multirow[t]{2}{*}{ Gene } & \multirow[t]{2}{*}{ Function } & \multicolumn{3}{|c|}{ Fold change } \\
\hline & & $7 \mathrm{~min}$ & $25 \mathrm{~min}$ & $45 \mathrm{~min}$ \\
\hline htpG & Heat shock protein 90 & 4.08 & 3.85 & 3.57 \\
\hline groEL & $\begin{array}{l}\text { Heat shock protein; } \\
\text { chaperonin GroEL }\end{array}$ & 8.18 & 9.93 & 8.94 \\
\hline groES & $\begin{array}{l}\text { Heat shock protein; } \\
\text { co-chaperonin GroES }\end{array}$ & 5.86 & 6.66 & 5.74 \\
\hline grpE & $\begin{array}{l}\text { Heat shock protein GrpE; } \\
\text { nucleotide exchange factor } \\
\text { for DnaKJ chaperone }\end{array}$ & 5.36 & 3.69 & 3.32 \\
\hline SEN1800 & $\begin{array}{l}\text { Heat shock protein; } \\
\text { HSP2O-like chaperone }\end{array}$ & 14.43 & 22.26 & 16.68 \\
\hline
\end{tabular}

Highlighted fold changes correspond to up-regulated (dark gray) and down-regulated (light gray) genes. (n.s.), fold changes with $p>0.05$.

body export machinery, were also down-regulated, in particular flgKL, fliDST, flgMN, and fliAZ. The fliA gene specifies the flagellum-specific sigma factor, $\sigma^{28}$, that regulates the class III genes (Hughes et al., 1993). The class III genes (motAB, cheAW, cheRBYZ, cheM, SEN3058, tcp, tsr, and fliB), encoding chemotaxis proteins and structural subunits of the flagellum, were also down-regulated. The FlhDC-regulated $y c g R$ and $y h j H$ genes (Ko and Park, 2000) were also strongly repressed (0.08- and 0.18 -fold at $45 \mathrm{~min}$ respectively; Table 8). The $y c g R$ gene regulates flagellar motility and $y h j H$ is involved in regulation of the switch from flagellar motility to sessile behavior and curli expression.

The IrhA gene, encoding "LysR homolog A," was 0.20-fold down-regulated at $45 \mathrm{~min}$. LrhA regulates the transcription of genes involved in the synthesis of type 1 fimbriae (Blumer, 2005). Indirectly, this protein also regulates the transcription of several genes involved in motility, chemotaxis and flagellum synthesis by directly controlling the expression of the master regulator FlhDC (Lehnen et al., 2002). The expression of flagella/motility/chemotaxis components is highly regulated by multiple environmental stimuli including stress factors such as heat-shock (Walker et al., 1999), extreme pH (Maurer et al., 2005), envelope stress (CpxAR dependent, De Wulf et al., 2002) and low iron content (via RyhB in Salmonella Typhimurum; Kim and Kwon, 2013b). These stresses are relevant to egg white exposure and so may well explain the down shift in motility/taxis genes observed here.

\section{Induction of the Kdp Potassium Uptake System}

Egg white exposure resulted in a significant stimulation of the genes specifying the high-affinity $\mathrm{K}^{+}$uptake system, Kdp. Kdp is a P-type ATPase composed of the $\mathrm{K}^{+}$transporter, $\mathrm{KdpABC}$, and the two-component regulator, KdpDE. $k d p A B C$ and $k d p D$ were induced by EWMM at $45^{\circ} \mathrm{C}$ (3.28- to 7.60 -fold at $45 \mathrm{~min}$, Table 9), although $k d p E$ was not affected. Potassium is a major cytoplasmic cation in bacteria being involved in maintenance of osmotic pressure and in regulation of cytoplasmic $\mathrm{pH}$. The Kdp system is activated when $\mathrm{K}^{+}$is limited, when cytoplasmic $\mathrm{pH}$ is suboptimal or when turgor pressure is decreased (Epstein, 2003). A variety of environmental conditions including the $\mathrm{pH}$, growth temperature and the concentration of other cationic solutes are known to additionally modulate the strength of the stimulus perceived by KdpD (Asha and Gowrishankar, 1993).

\section{Shift in Energy Metabolism and Catabolism Repression of Genes Involved in Respiration}

Many of the genes encoding proteins involved in energy generation under aerobic and/or anaerobic conditions were down regulated upon exposure to the EWMM at $45^{\circ} \mathrm{C}$ (0.05- to 0.70 -fold at $45 \mathrm{~min}$, Table 10). These include genes encoding for cytochrome bo (cyoABCDE), succinate dehydrogenase (sdhCDAB), NADH dehydrogenases I and II (ndh, nuoABCDEFGHIJKLM), formate dehydrogenase$\mathrm{O}(\mathrm{fdoIGH})$, anaerobic glycerol3-phosphate dehydrogenase $(g l p A B C)$, formate dehydrogenase-H $(f d h F)$, hydrogenases 1,2 , and 3 (hyaD, hybADEF, hycCDEFGHI, hydN, hypBC,), pyruvate formate lyase-activating enzyme ( $p f l A B E F, y f i D)$, and the reductases of nitrite, nitrate, sulfite, dimethylsulphoxide and fumarate (nirBD, napADF, asrAC dmsABC, torT, and frdABD, respectively). This set of repressed genes includes many that specify iron-containing proteins (Table 10). Indeed, many of the genes listed in Table $\mathbf{1 0}$ are reported to be RyhB/RfrAB, and/or Fur controlled in the Enterobacteriaceae (Table 10).

The E. coli nuo, $n d h$ and $s d h$ genes have also been reported to be repressed at high $\mathrm{pH}$ (Maurer et al., 2005) possibly through control by CpxAR (note that the cyo genes are also CpxAR repressed Raivio et al., 2013). The fdo and hyc genes are also regulated by $\mathrm{PspF}$ in response to high $\mathrm{pH}$ response (Jovanovic et al., 2006) and other genes are regulated by FlhDC (Table 10).

In summary, we observed down-regulation of most of the genes involved in energy generation by respiration and these effects are likely controlled by Fur/RfrAB, CpxAR, PspF, and/or FlhDC.

\section{Induction of Genes Involved in Utilization of Hexonates and Hexuronates and Carbohydrate Metabolism}

Surprisingly, exposure to EWMM at $45^{\circ} \mathrm{C}$ strongly induced three distinct gene clusters involved in hexonate/hexuronate utilization: the dgoRKADT operon; the $u x u A B-u x a C$ operon; and the SEN1433-6 genes. The dgo genes were 13.59- to 31.13-fold induced (at 45 min; Table 11) in EWMM. Their general function is believed to be in utilization of D-galactonate and 2-keto-3deoxygalactonate. dgoT is inferred to encode a $\mathrm{D}$-galactonate uptake system; $d g o A, d g o K$ and $d g o D$ are suggested to code for enzymes involved in the conversion of D-galactonate to pyruvate and glyceraldehyde-3-phosphate, and $d g o R$ encodes a GntR/FadR-related regulator likely acting as a D-galactonateresponsive transcriptional repressor of the dgo operon (Cooper, 1978; Zhou and Rudd, 2013). The uxuAB-uxaC operon is believed to be involved in mannonate utilization; these genes were induced by levels (10.68- to 28.2-fold, $45 \mathrm{~min}$, Table 11) similar to those observed for the dgo genes. The SEN14335 genes form a putative operon adjacent to the functionallyrelated and divergent SEN1436 gene. They are induced by 5.17to 33.38-fold (at $45 \mathrm{~min}$, Table 11), similar to $d g o$ and $u x u A B$ uxaC. The genes of the SEN1432-6 cluster specify three enzymes 
TABLE 7 | Metabolism and transport of amino acids.

\begin{tabular}{|c|c|c|c|c|}
\hline \multirow[t]{2}{*}{ Gene } & \multirow[t]{2}{*}{ Function } & \multicolumn{3}{|c|}{ Fold Change } \\
\hline & & $7 \mathrm{~min}$ & $25 \min$ & $45 \mathrm{~min}$ \\
\hline \multicolumn{5}{|c|}{ BRANCHED CHAIN AMINO ACIDS } \\
\hline ilvC & Ketol-acid reductoisomerase & 0.14 & 0.09 & 0.06 \\
\hline$i l v D$ & Dihydroxy-acid dehydratase & n.s. & 0.70 & 0.46 \\
\hline$i l v E$ & $\begin{array}{l}\text { Branched-chain amino acid } \\
\text { aminotransferase }\end{array}$ & 0.42 & 0.45 & 0.36 \\
\hline$i / v G$ & $\begin{array}{l}\text { Acetolactate synthase } 2 \text { catalytic } \\
\text { subunit }\end{array}$ & 0.50 & 0.49 & 0.41 \\
\hline$i l v M$ & $\begin{array}{l}\text { Acetolactate synthase } 2 \text { regulatory } \\
\text { subunit }\end{array}$ & 0.50 & 0.49 & 0.37 \\
\hline leuA & 2-isopropylmalate synthase & n.s. & 0.38 & 0.16 \\
\hline leuB & 3-isopropylmalate dehydrogenase & n.s. & 0.38 & 0.17 \\
\hline leuc & $\begin{array}{l}\text { Isopropylmalate isomerase large } \\
\text { subunit }\end{array}$ & n.s. & 0.45 & 0.18 \\
\hline leuD & $\begin{array}{l}\text { Isopropylmalate isomerase small } \\
\text { subunit }\end{array}$ & n.s. & 0.61 & 0.33 \\
\hline livF & $\begin{array}{l}\text { Leucine/isoleucine/valine transporter } \\
\text { ATP-binding subunit }\end{array}$ & n.s. & 0.67 & 0.48 \\
\hline $\operatorname{livG}$ & $\begin{array}{l}\text { Leucine/isoleucine/valine transporter } \\
\text { ATP-binding subunit }\end{array}$ & n.s. & 0.46 & 0.27 \\
\hline livk & Leucine-specific binding protein & n.s. & 0.39 & 0.22 \\
\hline livM & $\begin{array}{l}\text { Leucine/isoleucine/valine transporter } \\
\text { permease subunit }\end{array}$ & n.s. & 0.51 & 0.29 \\
\hline yeas & Leucine export protein LeuE & 0.54 & 0.45 & 0.32 \\
\hline \multicolumn{5}{|c|}{ AROMATIC AMINO ACIDS } \\
\hline $\operatorname{aroD}$ & 3-dehydroquinate dehydratase & n.s. & n.s. & 0.48 \\
\hline $\operatorname{aro} P$ & Aromatic amino acid transporter & n.s. & 0.55 & 0.35 \\
\hline $\operatorname{aroG}$ & $\begin{array}{l}\text { Phospho-2-dehydro-3-deoxyheptonate } \\
\text { aldolase }\end{array}$ & n.s. & 0.35 & 0.22 \\
\hline$m t r$ & Tryptophan permease & n.s. & 0.37 & 0.26 \\
\hline pheA & $\begin{array}{l}\text { Bifunctional chorismate } \\
\text { mutase/prephenate dehydratase }\end{array}$ & 0.27 & 0.35 & 0.36 \\
\hline $\operatorname{trp} A$ & Tryptophan synthase subunit alpha & n.s. & 0.61 & 0.34 \\
\hline $\operatorname{trp} B$ & Tryptophan synthase subunit beta & n.s. & 0.53 & 0.29 \\
\hline $\operatorname{trp} C$ & $\begin{array}{l}\text { Bifunctional indole-3-glycerol } \\
\text { phosphate synthase/ } \\
\text { phosphoribosylanthranilate isomerase }\end{array}$ & 0.43 & 0.34 & 0.19 \\
\hline $\operatorname{trpD}$ & $\begin{array}{l}\text { Bifunctional glutamine } \\
\text { amidotransferase/anthranilate } \\
\text { phosphoribosyltransferase }\end{array}$ & n.s. & 0.34 & 0.21 \\
\hline $\operatorname{trp} E$ & Anthranilate synthase component I & n.s. & 0.34 & 0.15 \\
\hline \multicolumn{5}{|c|}{ THREONINE } \\
\hline thra & $\begin{array}{l}\text { Bifunctional aspartokinase I/homeserine } \\
\text { dehydrogenase I }\end{array}$ & 0.29 & 0.28 & 0.15 \\
\hline thrB & Homoserine kinase & 0.33 & 0.38 & 0.22 \\
\hline thrC & Threonine synthase & n.s. & n.s. & 0.38 \\
\hline thrs & Threonyl-tRNA synthetase & 0.16 & 0.19 & 0.20 \\
\hline \multicolumn{5}{|c|}{ ARGININE } \\
\hline adi & Arginine decarboxylase & 0.54 & 0.30 & 0.24 \\
\hline artM & $\begin{array}{l}\text { Arginine transporter permease subunit } \\
\text { ArtM }\end{array}$ & 0.51 & 0.42 & 0.42 \\
\hline yjdE & Arginine:agmatin antiporter & 0.49 & 0.30 & 0.23 \\
\hline
\end{tabular}

(Continued)
TABLE 7 | Continued

\section{Gene Function}

Fold Change

$7 \mathrm{~min} \quad 25 \mathrm{~min} \quad 45 \mathrm{~min}$

\section{CYSTEINE}

$\begin{array}{llllll}\text { cysA } & \text { Sulfate/thiosulfate transporter subunit } & 0.36 & 0.34 & 0.22\end{array}$

$\begin{array}{lllll}\text { cys } B & \text { Transcriptional regulator CysB } & \text { n.s. } & 0.38 & 0.21\end{array}$

cysC Adenylylsulfate kinase

cysD Sulfate adenylyltransferase subunit 2

$\begin{array}{lll}\text { n.s. } & 0.61 \quad 0.3\end{array}$

cysH Phosphoadenosine phosphosulfate

n.s. n.s.

n.s. $\quad 0.63$

0.41

reductase

cysl Sulfite reductase subunit beta

cysJ Sulfite reductase (NADPH) flavoprotein beta subunit

cysM Cysteine synthase B

cysN Sulfate adenylyttransferase subunit 1

cysP Thiosulfate transporter subunit

cysU Sulfate/thiosulfate transporter subunit

cysW Sulfate/thiosulfate transporter permease subunit

yedO D-cysteine desulfhydrase

\section{ASPARAGINE, GLUTAMATE}

asnA Asparagine synthetase AsnA

asnB Asparagine synthetase B

gltB Glutamate synthase subunit alpha

gltD Glutamate synthase subunit beta

gltJ Glutamate/aspartate transport system permease protein GltJ

gltK Glutamate/aspartate transport system permease protein GltK

gltP Glutamate/aspartate:proton symporter

$\begin{array}{cll}\text { n.s. } & 0.76 \quad 0.43\end{array}$

n.s. $\quad$ n.s. $\quad 0.42$

$\begin{array}{lll}0.44 & 0.49 & 0.49\end{array}$

n.s. n.s. 0.43

n.s. $0.63 \quad 0.38$

n.s. $0.45 \quad 0.26$

$\begin{array}{lll}0.31 & 0.37 & 0.24\end{array}$

$\begin{array}{lll}0.42 & 0.42 & 0.40\end{array}$

\section{LYSINE}

cadB Lysine/cadaverine antiporter

IysA Diaminopimelate decarboxylase

\begin{tabular}{cc|} 
n.s. & n.s. $\quad 0.25$
\end{tabular}

IysC Aspartate kinase III

$\begin{array}{lll}0.36 & 0.37 & 0.36\end{array}$

$\begin{array}{lll}0.37 & 0.49 & 0.30\end{array}$

n.s. $0.68 \quad 0.41$

$0.52 \quad$ n.s. $\quad 0.45$

\begin{tabular}{l|l|l}
0.48 & $0.76 \quad 0.43$
\end{tabular}

$\begin{array}{lll}0.55 & 0.54 & 0.40\end{array}$

\section{OTHER AMINO-ACID OR PEPTIDE TRANSPORTERS}

dppA Periplasmic dipeptide transport protein precursor

dppB Dipeptide transporter permease DppB

$\begin{array}{lll}0.47 & 0.49 & 0.37\end{array}$

$d p p C$ Dipeptide transporter

$d p p D \quad$ Dipeptide transporter ATP-binding subunit

dppF Dipeptide transporter ATP-binding subunit

oppA Periplasmic oligopeptide-binding

$\begin{array}{lll}2.77 & 4.14 & 5.99\end{array}$

protein precursor (OppA)

oppB Oligopeptide transporter permease

oppC Oligopeptide transport system permease protein (OppC)

oppD Oligopeptide transporter ATP-binding component

yecC Putative amino-acid $A B C$ transporter ATP-binding protein

yecS Putative ABC transporter membrane protein

\begin{tabular}{|c|c|c|}
\hline n.s. & 0.35 & 0.19 \\
\hline 0.37 & 0.40 & 0.24 \\
\hline n.s. & n.s. & 0.33 \\
\hline 0.40 & 0.51 & 0.30 \\
\hline & & \\
\hline 0.44 & 0.55 & 0.39 \\
\hline
\end{tabular}

n.s. $\quad 0.64 \quad 0.36$

$\begin{array}{ccc}\text { n.s. } & 0.54 \quad 0.27\end{array}$

\begin{tabular}{l|l|l}
0.47 & 0.49 & 0.34
\end{tabular}

$0.57 \quad 0.74 \quad 0.46$

$0.41 \quad 0.41 \quad 0.40$

$0.38 \quad 0.40 \quad 0.41$

Highlighted fold changes correspond to up-regulated (dark gray) and down-regulated (light gray) genes. (n.s.), fold changes with $p>0.05$. 
TABLE 8 | Motility and taxis.

\begin{tabular}{|c|c|c|c|c|}
\hline \multirow[t]{2}{*}{ Gene } & \multirow[t]{2}{*}{ Function } & \multicolumn{3}{|c|}{ Fold change } \\
\hline & & $7 \mathrm{~min}$ & $25 \mathrm{~min}$ & $45 \min$ \\
\hline \multicolumn{5}{|c|}{ FLAGELLA BIOSYNTHESIS } \\
\hline flgK & $\begin{array}{l}\text { Flagellar hook-associated } \\
\text { protein FlgK }\end{array}$ & n.s. & 0.15 & 0.10 \\
\hline$f l g L$ & $\begin{array}{l}\text { Flagellar hook-associated } \\
\text { protein FlgL }\end{array}$ & n.s. & 0.28 & 0.18 \\
\hline$f l g M$ & Anti-sigma28 factor FlgM & n.s. & 0.28 & 0.14 \\
\hline$f \lg N$ & $\begin{array}{l}\text { Flagella synthesis chaperone } \\
\text { protein FlgN }\end{array}$ & n.s. & 0.26 & 0.15 \\
\hline$f l h B$ & $\begin{array}{l}\text { Flagellar biosynthesis protein } \\
\text { FlhB }\end{array}$ & 0.26 & 0.25 & 0.23 \\
\hline flhC & Transcriptional activator FlhC & 0.61 & 0.52 & 0.41 \\
\hline$f l h D$ & Transcriptional activator FlhD & 0.51 & 0.40 & 0.34 \\
\hline fliA & $\begin{array}{l}\text { Flagellar biosynthesis sigma } \\
\text { factor }\end{array}$ & n.s. & 0.12 & 0.07 \\
\hline fliB & Lysine-N-methylase & 0.14 & 0.08 & 0.06 \\
\hline fliD & Flagellar capping protein & n.s. & 0.18 & 0.07 \\
\hline flis & Flagellar protein Flis & n.s. & 0.18 & 0.07 \\
\hline fliT & $\begin{array}{l}\text { Flagellar biosynthesis protein } \\
\text { FliT }\end{array}$ & n.s. & 0.16 & 0.06 \\
\hline fliz & Flagella biosynthesis protein FliZ & n.s. & 0.14 & 0.08 \\
\hline motA & Flagellar motor protein MotA & 0.37 & 0.20 & 0.14 \\
\hline $\operatorname{mot} B$ & Flagellar motor protein MotB & n.s. & 0.24 & 0.14 \\
\hline \multicolumn{5}{|c|}{ CHEMOTAXIS } \\
\hline cheA & Chemotaxis protein CheA & n.s. & 0.25 & 0.14 \\
\hline cheB & $\begin{array}{l}\text { Chemotaxis-specific } \\
\text { methylesterase }\end{array}$ & 0.39 & 0.32 & 0.25 \\
\hline cheM & $\begin{array}{l}\text { Methyl-accepting chemotaxis } \\
\text { protein II }\end{array}$ & n.s. & 0.20 & 0.12 \\
\hline cheR & $\begin{array}{l}\text { Chemotaxis methyltransferase } \\
\text { CheR }\end{array}$ & 0.33 & 0.22 & 0.16 \\
\hline chew & $\begin{array}{l}\text { Purine-binding chemotaxis } \\
\text { protein }\end{array}$ & n.s. & 0.40 & 0.21 \\
\hline cheY & $\begin{array}{l}\text { Chemotaxis regulatory protein } \\
\text { CheY }\end{array}$ & n.s. & 0.42 & 0.24 \\
\hline cheZ & Chemotaxis regulator CheZ & n.s. & 0.42 & 0.27 \\
\hline SEN2296 & Chemotaxis protein CheV & 0.18 & 0.10 & 0.06 \\
\hline SEN3058 & $\begin{array}{l}\text { Methyl-accepting chemotaxis } \\
\text { protein II }\end{array}$ & n.s. & 0.19 & 0.10 \\
\hline tcp & $\begin{array}{l}\text { Methyl-accepting chemotaxis } \\
\text { citrate transducer }\end{array}$ & 0.15 & 0.08 & 0.05 \\
\hline tsr & $\begin{array}{l}\text { Methyl-accepting chemotaxis } \\
\text { protein }\end{array}$ & n.s. & 0.21 & 0.14 \\
\hline \multicolumn{5}{|c|}{ MOTILITY REGULATION } \\
\hline aer & Aerotaxis receptor protein & n.s. & 0.50 & 0.42 \\
\hline $\operatorname{lrh} A$ & Transcriptional regulator & 0.37 & 0.29 & 0.20 \\
\hline$y \operatorname{cg} R$ & Flagellar brake protein YcgR & n.s. & 0.20 & 0.08 \\
\hline yhjH & $\begin{array}{l}\text { Cyclic-guanylate-specific } \\
\text { phosphodiesterase }\end{array}$ & n.s. & 0.23 & 0.18 \\
\hline
\end{tabular}

Highlighted fold changes correspond to up-regulated (dark gray) and down-regulated (light gray) genes. (n.s.): fold changes with $p>0.05$.

(two suspected dehydrogenases and one dehydratase), likely to be involved in hexonate utilization, and a proposed hexonate transporter.
TABLE 9 | High-affinity potassium uptake.

\begin{tabular}{|c|c|c|c|c|}
\hline \multirow[t]{2}{*}{ Gene } & \multirow[t]{2}{*}{ Function } & \multicolumn{3}{|c|}{ Fold change } \\
\hline & & $7 \mathrm{~min}$ & $25 \mathrm{~min}$ & $45 \mathrm{~min}$ \\
\hline$k d p A$ & $\begin{array}{l}\text { Potassium-transporting ATPase } \\
\text { subunit A }\end{array}$ & 2.75 & 3.60 & 5.74 \\
\hline$k d p B$ & $\begin{array}{l}\text { Potassium-transporting ATPase } \\
\text { subunit B }\end{array}$ & 2.68 & 3.16 & 5.28 \\
\hline$k d p C$ & $\begin{array}{l}\text { Potassium-transporting ATPase } \\
\text { subunit C }\end{array}$ & 3.17 & 5.05 & 7.60 \\
\hline$k d p D$ & Sensor kinase KdpD & n.s. & 2.29 & 3.28 \\
\hline
\end{tabular}

Highlighted fold changes correspond to up-regulated (dark gray) and down-regulated (light gray) genes. (n.s.), fold changes with $p>0.05$.

A subset of genes encoding phosphotransferase components, involved in the uptake of carbohydrate, was also induced ( $p t s H$, $p t s A(f r w A), f r w B C$, treB) in EWMM, as were several genes specifying glycolysis and pentose phosphate pathway enzymes (gapA, gpmA, pykA, fbaB, pfkB, talC, rpiA, tktA), by 1.99- to 5.62 -fold at $45 \mathrm{~min}$ (Table 11). Six genes involved in the one carbon pathway and degradation of serine, glycine and threonine to pyruvate and ammonia were also induced by EWMM ( $g c v T$, $g c v H, s d a A, g l y A, k b l, t d h, s e r B$; Table 11). Both the $g l y A$ and $s d a A$ genes of $E$. coli were up-regulated by heat shock (Nonaka et al., 2006; Wolfe et al., 2008; Lüders et al., 2009). Indeed, the acetate kinase $(a c k A)$ and ethanol dehydrogenase ( $a d h P)$ genes encoding mixed-acid fermentation enzymes were induced (Table 11). In contrast, several genes of the TCA cycle ( $s d h C D A B$, Table 10; $l p d A$ and $a c n A B$, Table 11) were 0.36 - to 0.48 -fold down-regulated in EWMM.

In summary, exposure to EWMM at $45^{\circ} \mathrm{C}$ provoked changes in carbohydrate metabolism involving activation of the hexonate/hexuronate, pentose phosphate, glycolysis pathways and repression of the TCA cycle.

\section{Confirmation of Microarray Data by qRT-PCR}

To confirm the validity of the expression effects observed by microarray analysis, qRT-PCR was used to determine the expression changes of six genes following incubation in EWMM for $45 \mathrm{~min}$ at $45^{\circ} \mathrm{C}$ (Table 12). The six genes selected for analysis were from four different, relevant functional groups and included those displaying the highest differential expression effects (iroB, $f e s$, and $f t n$ for iron acquisition, bioB for biotin synthesis, $d g o K$ for hexonate metabolism and spy for envelope stress). The qRT-PCR data confirm the expression change of the six genes in response to exposure of $S$. Enteritidis to EWMM, although qRT-PCR indicated a greater degree of regulation (3- to 24-fold higher) than the microarray analysis, as previously reported (Franchini, 2006). Thus, the qRT-PCR data support the induction of the iron restriction, hexonate catabolism, biotin biosynthesis and envelope-stress genes in EWMM and therefore provide support for the reliability of the expression effects revealed by microarray analysis (Tables 2-11). 
TABLE 10 | Energy metabolism.

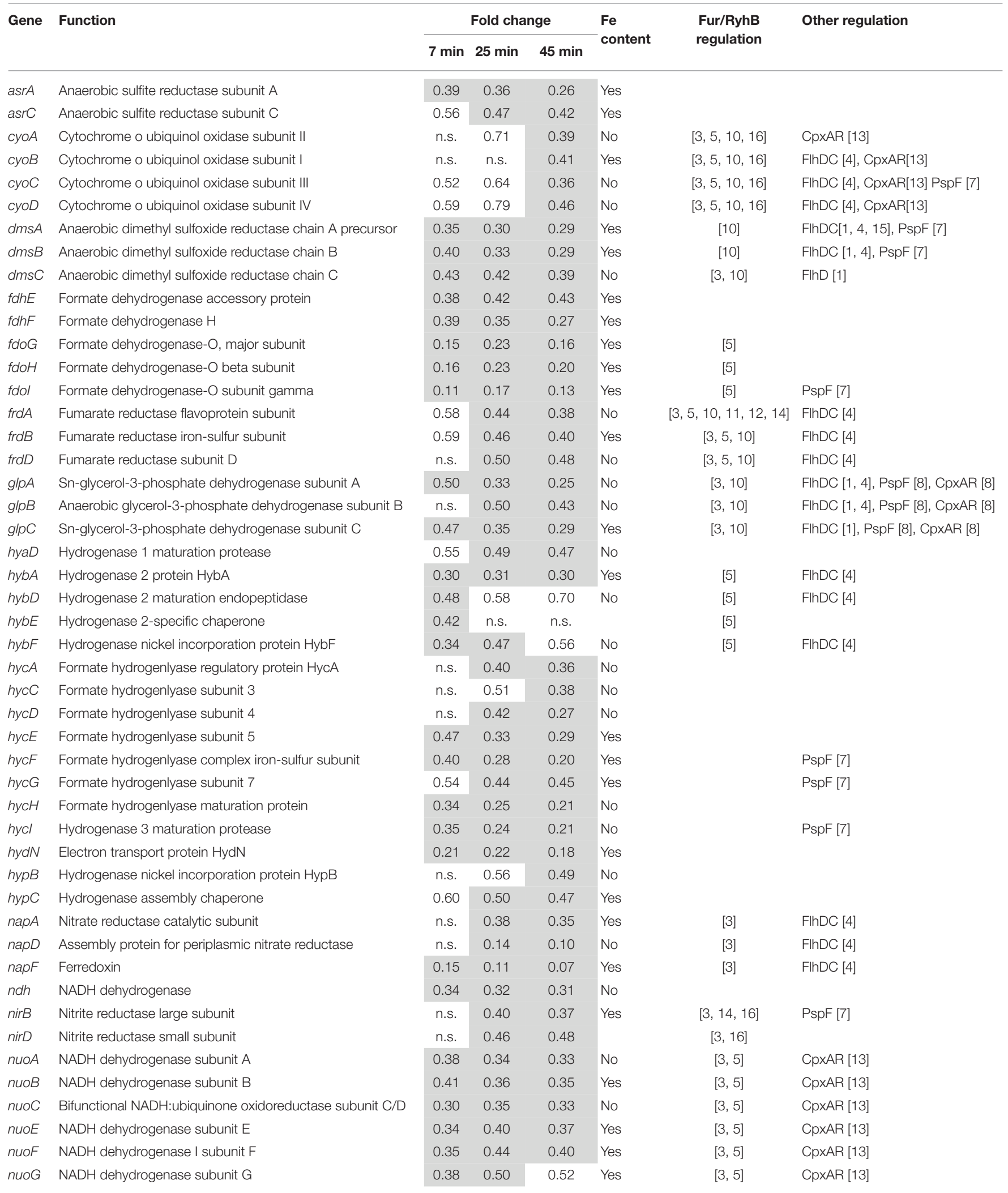


TABLE 10 | Continued

\begin{tabular}{|c|c|c|c|c|c|c|c|}
\hline \multirow[t]{2}{*}{ Gene } & \multirow[t]{2}{*}{ Function } & \multicolumn{3}{|c|}{ Fold change } & \multirow{2}{*}{$\begin{array}{l}\text { Fe } \\
\text { content }\end{array}$} & \multirow{2}{*}{$\begin{array}{l}\text { Fur/RyhB } \\
\text { regulation }\end{array}$} & \multirow[t]{2}{*}{ Other regulation } \\
\hline & & $7 \mathrm{~min}$ & $25 \mathrm{~min}$ & $45 \mathrm{~min}$ & & & \\
\hline nuoH & $\mathrm{NADH}$ dehydrogenase subunit $\mathrm{H}$ & 0.22 & 0.34 & 0.33 & No & {$[3,5]$} & CpxAR [13] \\
\hline nuol & NADH dehydrogenase subunit I & 0.24 & 0.36 & 0.36 & Yes & {$[3,5]$} & CpxAR [13] \\
\hline nuoJ & NADH dehydrogenase subunit $J$ & 0.27 & 0.39 & 0.39 & No & {$[3,5]$} & CpxAR [13] \\
\hline nuok & $\mathrm{NADH}$ dehydrogenase subunit $\mathrm{K}$ & 0.27 & 0.42 & 0.41 & No & {$[3,5]$} & CpxAR [13] \\
\hline nuol & NADH dehydrogenase subunit $L$ & 0.31 & 0.56 & 0.56 & No & {$[3,5]$} & CpxAR [13] \\
\hline nuoM & NADH dehydrogenase subunit M & 0.39 & 0.61 & 0.64 & No & {$[3,5]$} & CpxAR [13] \\
\hline$p f l A$ & Pyruvate formate lyase-activating enzyme 1 & 0.65 & 0.56 & 0.44 & Yes & & \\
\hline pflB & Formate acetyltransferase 1 & n.s. & 0.45 & 0.50 & No & & \\
\hline pflE & Putative pyruvate formate-lyase 3 activating enzyme & 0.14 & 0.15 & 0.12 & No & & \\
\hline pflF & Putative formate acetyltransferase 3 & 0.14 & 0.16 & 0.14 & No & {$[12]$} & \\
\hline sdhA & Succinate dehydrogenase flavoprotein subunit & n.s. & 0.60 & 0.33 & No & {$[2,5,10,14]$} & FlhDC [4], CpxAR[13] \\
\hline$s d h B$ & Succinate dehydrogenase iron-sulfur subunit & n.s. & n.s. & 0.45 & Yes & {$[2,5,6]$} & FlhDC [4], CpxAR[13] \\
\hline$s d h C$ & $\begin{array}{l}\text { Succinate dehydrogenase cytochrome b556 large membrane } \\
\text { subunit }\end{array}$ & 0.50 & 0.63 & 0.44 & Yes & {$[2,5,6,9,14]$} & FlhDC [4], CpxAR[13] \\
\hline$s d h D$ & $\begin{array}{l}\text { Succinate dehydrogenase cytochrome b556 small membrane } \\
\text { subunit }\end{array}$ & 0.41 & 0.60 & 0.35 & Yes & {$[2,5,6,14]$} & FlhDC [4], CpxAR[13] \\
\hline torT & TMAO reductase system periplasmic protein TorT & 0.45 & 0.45 & 0.35 & No & & \\
\hline yfiD & $\begin{array}{l}\text { Autonomous glycyl radical cofactor GrcA, stress-induced } \\
\text { alternate pyruvate formate-lyase subunit }\end{array}$ & 0.13 & 0.05 & 0.05 & No & {$[9]$} & FlhDC [4] \\
\hline
\end{tabular}

Highlighted fold changes correspond to up-regulated (dark gray) and down-regulated (light gray) genes. (n.s.), fold changes with $p>0.05$.

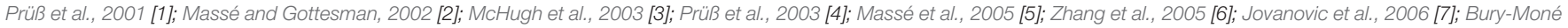

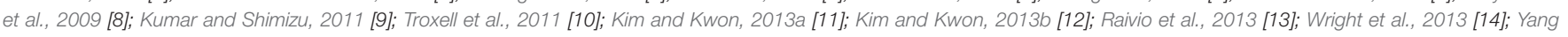
et al., 2013 [15]; Calderón et al., 2014 [16].

\section{DISCUSSION}

\section{Overview}

Here we describe the first global-transcriptional analysis of the response of $S$. Enteritidis to egg white exposure under bactericidal conditions, providing a unique insight into egg white antibacterial activity. In order to enable this study, an "egg white model medium" (EWMM) was employed that lacks the problematic viscosity of egg white. This medium was shown to retain the bacteriostatic and bactericidal activity of egg white at 30 and $45^{\circ} \mathrm{C}$, respectively, which supports previous work showing EWMM to be an appropriate mimick of egg white (Baron et al., 1997; Alabdeh et al., 2011). This bactericidal action clearly requires the combined action of temperature with egg white as $S$. Enteritidis is not subject to substantial killing in TSB at $45^{\circ} \mathrm{C}$ nor in egg white at lower temperature $\left(30^{\circ} \mathrm{C}\right)$. Previous work showed only a moderate bactericidal activity for egg white at $42^{\circ} \mathrm{C}$ (reduction of less than $2 \log _{10}$ $\mathrm{CFU} / \mathrm{ml}$ to $3.5 \log _{10} \mathrm{CFU} / \mathrm{ml}$ for $S$. Enteritidis during a $24-$ 96 h incubation; Guan et al., 2006; Kang et al., 2006; Raspoet et al., 2014) whereas a complete bactericidal effect was seen at $45^{\circ} \mathrm{C}$ (Alabdeh et al., 2011). This observation matches a previous study (Liot and Anza, 1996) showing that bacterial destruction by liquid egg white treatment (as used in the food industry) is optimal at $42-45^{\circ} \mathrm{C}$. Thus, incubation at $45^{\circ} \mathrm{C}$ in EWMM (as employed here) represents ideal conditions for examination of the response of $S$. Enteritidis to the bactericidal activity of egg white. Relatively short incubation times $(7-45 \mathrm{~min})$ were used since prolonged EWMM exposure results in total cell death at $24 \mathrm{~h}$.

\section{Transcriptional Response of S. Enteritidis to EWMM}

Incubation of $S$. Enteritidis in EWMM at $45^{\circ} \mathrm{C}$ provoked a major transcriptional response $(18.7 \%$ of genes affected at 45 min) indicative of a substantial shift in cellular physiology. Of the differentially-regulated genes, $49.2 \%$ were assigned to one of eleven functional classes, as described in the Results section, reflecting specific physiological alterations caused by egg white exposure. Among the remaining genes, most (47.3\%) have either unknown or hypothetical function. The eleven functional classes thus defined were divided into three broad categories: nutrient deprivation; cell damage/stress; and a shift in energy metabolism and catabolism (Figure 2). The majority of these changes correlate well with previous findings and with the conditions associated with egg white (Baron et al., 2016).

\section{Nutrient Deprivation}

The strong induction of the bio operon (Table 2) is fully consistent with results suggesting a role for the bioB gene in egg white survival at $42^{\circ} \mathrm{C}$ (Raspoet et al., 2014) and can be considered to represent a rational physiological response of $S$. Enteritidis to the poor biotin avaibility in egg white resulting from the presence of avidin, a powerful biotin-chelation protein (Banks et al., 1986; Beckett, 2007) that thus supports the 
TABLE 11 | Hexonate and hexuronate utilization and carbohydrate metabolism.

\begin{tabular}{|c|c|c|c|c|}
\hline \multirow[t]{2}{*}{ Gene } & \multirow[t]{2}{*}{ Function } & \multicolumn{3}{|c|}{ Fold change } \\
\hline & & $7 \mathrm{~min}$ & $25 \mathrm{~min}$ & $45 \mathrm{~min}$ \\
\hline \multicolumn{5}{|c|}{ GLYCOLYSIS/HEXOSE METABOLISM } \\
\hline$f b a B$ & Fructose-bisphosphate aldolase & 2.27 & 2.98 & 4.28 \\
\hline frwB & $\begin{array}{l}\text { Putative fructose-like } \\
\text { phosphotransferase EllB subunit } 2\end{array}$ & 2.28 & 2.52 & 2.56 \\
\hline frwC & $\begin{array}{l}\text { Putative fructose-like permease EIIC } \\
\text { subunit } 2\end{array}$ & 1.59 & 2.35 & 2.17 \\
\hline gapA & $\begin{array}{l}\text { Glyceraldehyde 3-phosphate } \\
\text { dehydrogenase A }\end{array}$ & 3.10 & 2.33 & 2.02 \\
\hline gpmA & Phosphoglycerate mutase 1 & 1.48 & 1.94 & 2.14 \\
\hline$p f k B$ & 6-phosphofructokinase 2 & 4.53 & 5.47 & 4.87 \\
\hline $\begin{array}{l}\text { ptsA } \\
(\text { frwA) }\end{array}$ & $\begin{array}{l}\text { Phosphoenolpyruvate-protein } \\
\text { phosphotransferase }\end{array}$ & 1.69 & 2.26 & 2.53 \\
\hline ptsH & $\begin{array}{l}\text { Phosphohistidinoprotein-hexose } \\
\text { phosphotransferase component of PTS } \\
\text { system (HPr) }\end{array}$ & 1.76 & 2.07 & 2.28 \\
\hline pykA & Pyruvate kinase & n.s. & 1.73 & 1.99 \\
\hline talc & Fructose-6-phosphate aldolase & 2.88 & 5.38 & 5.62 \\
\hline $\operatorname{treB}$ & $\begin{array}{l}\text { Trehalose(maltose)-specific PTS system } \\
\text { components IIBC }\end{array}$ & 2.52 & 2.49 & 2.27 \\
\hline \multicolumn{5}{|c|}{ ONE CARBON PATHWAY } \\
\hline$g C v A$ & $\begin{array}{l}\text { DNA-binding transcriptional activator } \\
\text { GcvA }\end{array}$ & n.s. & 0.62 & 0.39 \\
\hline$g c v H$ & Glycine cleavage system protein $\mathrm{H}$ & 1.94 & 2.00 & 2.15 \\
\hline gcvT & $\begin{array}{l}\text { Glycine cleavage system } \\
\text { aminomethyltransferase } T\end{array}$ & 2.13 & 2.08 & 2.12 \\
\hline kbl & $\begin{array}{l}\text { 2-amino-3-ketobutyrate coenzyme A } \\
\text { ligase }\end{array}$ & 2.65 & 2.20 & 2.00 \\
\hline$t d h$ & L-threonine 3-dehydrogenase & 2.23 & 1.80 & 1.64 \\
\hline glyA & Serine hydroxymethyltransferase & 3.40 & 2.83 & 2.56 \\
\hline$s d a A$ & L-serine deaminase 1 & 3.03 & 3.54 & 3.34 \\
\hline $\operatorname{ser} B$ & Phosphoserine phosphatase & 2.85 & 2.40 & 2.75 \\
\hline \multicolumn{5}{|c|}{ TCA CYCLE } \\
\hline aceE & Pyruvate dehydrogenase subunit E1 & 0.21 & 0.36 & 0.36 \\
\hline aceF & Dihydrolipoamide acetyltransferase & 0.23 & 0.44 & 0.43 \\
\hline acnA & Aconitate hydratase & 0.45 & 0.51 & 0.37 \\
\hline$a c n B$ & $\begin{array}{l}\text { Bifunctional aconitate hydratase } \\
\text { 2/2-methylisocitrate dehydratase }\end{array}$ & 0.29 & 0.35 & 0.27 \\
\hline IpdA & Dihydrolipoamide dehydrogenase & 0.30 & 0.50 & 0.48 \\
\hline \multicolumn{5}{|c|}{ MIXED FERMENTATION } \\
\hline ackA & Acetate kinase & n.s. & 2.02 & 2.23 \\
\hline adhP & Alcohol dehydrogenase & n.s. & 2.22 & 1.95 \\
\hline \multicolumn{5}{|c|}{ PENTOSE PHOSPHATE SHUNT (NON-OXIDATIVE BRANCH) } \\
\hline rpiA & Ribose-5-phosphate isomerase A & 3.01 & 2.24 & 2.15 \\
\hline tktA & Transketolase & 2.94 & 2.91 & 3.17 \\
\hline \multicolumn{5}{|c|}{ D-GALACTONATE UTILIZATION } \\
\hline$d g \circ A$ & D-galactonate dehydratase (SEN3644) & 5.87 & 26.22 & 24.85 \\
\hline$d g o D$ & $\begin{array}{l}\text { 2-dehydro-3-deoxy-6- } \\
\text { phosphogalactonate aldolase } \\
\text { (SEN3645) }\end{array}$ & 6.67 & 23.93 & 22.03 \\
\hline dgoK & 2-dehydro-3-deoxygalactonokinase & 9.47 & 34.35 & 31.13 \\
\hline$d g o R$ & $\begin{array}{l}\text { Galactonate operon transcriptional } \\
\text { repressor }\end{array}$ & 8.96 & 28.70 & 27.13 \\
\hline
\end{tabular}

(Continued)
TABLE 11 | Continued

\begin{tabular}{|c|c|c|c|c|}
\hline \multirow[t]{2}{*}{ Gene } & \multirow[t]{2}{*}{ Function } & \multicolumn{3}{|c|}{ Fold change } \\
\hline & & $7 \mathrm{~min}$ & $25 \mathrm{~min}$ & $45 \mathrm{~min}$ \\
\hline dgot & D-galactonate transporter & n.s. & 10.77 & 13.59 \\
\hline$d k g B$ & 2,5-diketo-D-gluconate reductase B & 2.89 & 2.19 & 2.85 \\
\hline yiaE & Putative 2-hydroxyacid dehydrogenase & 2.05 & 2.04 & 2.07 \\
\hline \multicolumn{5}{|c|}{ MANNONATE UTILIZATION } \\
\hline SEN2978 & Mannonate dehydratase (uxuA) & 4.39 & 24.16 & 28.19 \\
\hline SEN2979 & D-mannonate oxidoreductase $(u \times u B)$ & n.s. & 16.77 & 19.11 \\
\hline SEN2980 & $\begin{array}{l}\text { Glucuronate isomerase; uronate } \\
\text { isomerase; uronic isomerase (uxaC) }\end{array}$ & n.s. & 8.81 & 10.68 \\
\hline \multicolumn{5}{|c|}{ HEXONATE UTILIZATION } \\
\hline eda & $\begin{array}{l}\text { Keto-hydroxyglutarate-aldolase/keto- } \\
\text { deoxy-phosphogluconate } \\
\text { aldolase }\end{array}$ & 2.09 & 2.01 & 1.94 \\
\hline SEN1433 & L-idonate 5-dehydrogenase IdnD & 3.05 & 3.21 & 5.17 \\
\hline SEN1434 & Hexonate sugar transporter & n.s. & 2.70 & 5.68 \\
\hline SEN1435 & Gluconate 5-dehydrogenase & n.s. & 3.07 & 7.40 \\
\hline SEN1436 & $\begin{array}{l}\text { D-galactonate dehydratase family } \\
\text { member SEN1436 }\end{array}$ & n.s. & 10.30 & 33.38 \\
\hline
\end{tabular}

Highlighted fold changes correspond to up-regulated (dark gray) and down-regulated (light gray) genes. (n.s.), fold changes with $p>0.05$.

TABLE 12 | Confirmation of selected genes by qRT-PCR analysis.

\begin{tabular}{|c|c|c|c|}
\hline \multirow[t]{2}{*}{ Gene } & \multirow[t]{2}{*}{ Function } & \multicolumn{2}{|c|}{ Fold change $\left(45^{\circ} \mathrm{C}, 45 \mathrm{~min}\right)$} \\
\hline & & RT-PCR* & Microarray \\
\hline bio $B$ & Biotin synthetase, biotin synthesis & $172.7( \pm 34.5)$ & 23.4 \\
\hline dgoK & $\begin{array}{l}\text { 2-dehydro-3-deoxygalactonokinase } \\
\text { hexonate metabolism }\end{array}$ & $240.2( \pm 44.3)$ & 31.1 \\
\hline fes & $\begin{array}{l}\text { Ferric enterobactin esterase, iron } \\
\text { uptake }\end{array}$ & $285.5( \pm 87.5)$ & 11.9 \\
\hline $\operatorname{ftn} A$ & Ferritin, iron storage & $0.76( \pm 0.04)$ & 0.19 \\
\hline $\operatorname{iroB}$ & Salmochelin synthesis, iron uptake & $14.9( \pm 1.4)$ & 4.1 \\
\hline spy & Spheroplast formation & $64.5( \pm 32.7)$ & 22.2 \\
\hline
\end{tabular}

Highlighted fold changes correspond to up-regulated (dark gray) and down-regulated (light gray) genes.

${ }^{*}$ Calculation of fold change by qRT-PCR was determined from the number of RNA copies after 45 min of incubation divided by the number of RNA copies at $T=0)$. A total of two $R N A$ extractions were performed using distinct $S$. Enteritidis cultures grown on different batches of EWMM. Each of the two RNA extracts thus obtained was subject to qRT-PCR, in triplicate, for each gene. Data were normalized using values for three internal control genes (asmA, emrA, orf32). Standard deviations are calculated from two sets of triplicate data are in parentheses.

validity of the array data. Likewise, the comprehensive induction of genes involved in the iron-starvation response (Table 3 ) supports the notion that egg white represents an iron-restricted environment for Salmonella. These findings corroborate a number of previous studies suggesting that a major contributor to the bacteria-growth inhibition capacity of egg white is the imposition of iron deficiency, generated largely as a consequence of the strong ferric-iron chelation activity of ovotransferrin (Garibaldi, 1970; Lock and Board, 1992; Baron et al., 1997; Kang et al., 2006). Indeed, previous studies have shown that 
$S$. Enteritidis iron-acquisition mutants (entF and entF/feoAB) are attenuated for survival in egg white (Kang et al., 2006) providing additional evidence for the iron-restricted nature of egg white. This effect appears to be coordinated by the global Feregulator, Fur, and incorporates the following effects: induction of iron-uptake pathways; down-regulation of iron-storage capacity (along with the probable mobilization of iron stores); induction of the alternative $\mathrm{Fe}-\mathrm{S}$ cluster manufacturing pathway; iron rationing with replacement of iron-dependent proteins by manganese-dependent alternatives; and induction of manganese uptake to supply $\mathrm{Mn}^{2+}$ to the newly-induced $\mathrm{Mn}$-dependent isoenzymes.

The down-regulation of a set of virulence genes (Table 4) associated with the SPI-1 locus (all members of the Fur modulon) correlates with the iron-restriction imposed by egg white (Teixidó et al., 2011).

\section{Cell Damage/stress}

The expression data were consistent with a considerable membrane-stress response (Table 5). The up-regulation of spy is consistent with the microscopy observation made on $E$. coli in the same conditions (Jan et al., 2013), where incubation in EWMM for $45 \mathrm{~min}$ at $45^{\circ} \mathrm{C}$ caused formation of spheroplasts. The induction of $\operatorname{deg} P$, encoding an endoprotease that degrades abnormal proteins, is consistent with previous studies. Mo et al. (2006) showed that DegP is required for survival of Salmonella Typhimurium at high temperatures and Raspoet et al. (2014) reveal its role in survival of $S$. Enteritidis in egg white at $42^{\circ} \mathrm{C}$. The genes of the Tol-Pal system involved in the maintenance of cell-envelope integrity were also induced.

The observed change in the porin-expression profile (up regulation of $o m p C$ and down regulation of $o m p F$ ) would be consistent with an attempt by $S$. Enteritidis to protect itself from the antimicrobial activities within egg white. The reciprocal regulation of $o m p C$ and $o m p F$ might enable the cell to continue to acquire nutrients whilst limiting exposure to toxins by utilizing OmpC (smaller pore size) in place of OmpF (Nikaido, 1996; Batchelor et al., 2005). Replacing the general-diffusion porins with porins of smaller pore-size is a recognized antibioticresistance strategy (Delcour, 2009).

Induction of several peptidoglycan hydrolase genes (dacC, dacD amiC, $m l t A, m l t D$, emtA, yfhD) was another feature of the microarray data. Up-regulation of $a m i C$ is already recognized to enhance survival of $E$. coli during treatment with the antimicrobial peptide protamine (Weatherspoon-Griffin et al., 2011). The up-regulation of peptidoglycan hydrolases is suggested to induce a remodeling of the peptidoglycan in response to environmental challenge and so would be fully consistent with an envelope-stress response. However, it should be noted that expression of the major peptidoglycans synthetases ( $m c r A, m c r B, p b p A, p b p B, p b p C$, ftsI, and $m t g A$; data not shown) was not significantly affected. Appropriate balance between peptidoglycan synthesis and hydrolysis is critical for cell integrity (Meisel et al., 2003; Kumar et al., 2012). The apparent imbalance in their respective expression levels upon EWMM exposure might result in excessive peptidoglycan hydrolysis leading to loss of integrity of the peptidoglycan layer, which would be expected to promote spheroplast formation as seen for E. coli EWMM exposure (Jan et al., 2013).

The induction of the $p s p A D E G$ genes observed here is consistent with the $p s p$ response previously described in E. coli and Salmonella Typhimurium where up regulation of $p s p A$ and $p s p G$ was triggered by the reduction of the pmf, without effect on other psp genes (Lloyd et al., 2004). These results are also consistent with the production of PspA in response to heat stress at $45^{\circ} \mathrm{C}$ (Hassani et al., 2009). There are at least two factors (ovotransferrin and high $\mathrm{pH}$ ) in egg white that can cause dissipation of the pmf and which could thus induce the observed psp response (Aguilera et al., 2003; Darwin, 2005).

The expression data indicate a major induction of membranestress related genes in cells exposed to EWMM at $45^{\circ} \mathrm{C}$, likely mediated by the transcriptional regulators $\mathrm{CpxR}, \mathrm{OmpR}$ and PspF (Figure 2). The probable environmental factors triggering this effect in EWMM are antimicrobial egg white components (Kohanski et al., 2008; Laubacher and Ades, 2008; Farris et al., 2010; Audrain et al., 2013; Evans et al., 2013; Raivio et al., 2013; Raivio, 2014), pmf dissipation (Weiner and Model, 1994; Kleerebezem et al., 1996; Joly et al., 2010) and alkaline pH (Danese and Silhavy, 1998; Thede et al., 2011; Tschauner et al., 2014) along with temperature (Brissette et al., 1990; Danese and Silhavy, 1998; Raivio and Silhavy, 2001; Darwin, 2005; Joly et al., 2010; Raivio, 2014). Previous work has also suggested that maintenance of cell-envelope integrity is an important facet of resistance to egg white (Gantois et al., 2008a), with cellwall disruption and progressive cell lysis reported as the major mechanisms of egg white-mediated bactericidal action at $45^{\circ} \mathrm{C}$ for E. coli (Jan et al., 2013).

Heat-shock proteins under $\mathrm{RpoH}$ control (Rouvière et al., 1995) were also induced (Table 6), presumably in response to the temperature upshift experienced by $S$. Enteritidis upon transfer of the inoculum $\left(37^{\circ} \mathrm{C}\right)$ to $\mathrm{EWMM}\left(45^{\circ} \mathrm{C}\right)$. This type of induction was also observed in E. coli, (Arsène et al., 2000; Guisbert et al., 2008) and indicates that $S$. Enteritidis suffers heat-shock under the conditions employed here. In addition, the induction of a "ribosomal-stress response," and the large-scale repression of genes required for amino-acid biosynthesis and uptake (Table 7), suggest a translational shutdown. It is likely that this translational down-regulation is caused by the unfavorable growth conditions imposed by the hostile conditions of EWMM at $45^{\circ} \mathrm{C}$ resulting in a block in protein production through interference with ribosome activity possibly arising from reduced amino acid availability or from a direct effect of temperature on the ribosome (Starosta et al., 2014).

It should be noted that amino acid synthesis is considered important for survival in egg white at $37^{\circ} \mathrm{C}$ (Clavijo et al., 2006; Gantois et al., 2008a). However, the conditions used here $\left(45^{\circ} \mathrm{C}\right)$ are bactericidal and so no growth is expected, and thus amino acid production is unlikely to be a major requirement and this would be consistent with a reduced anabolic demand probably resulting from the cessation of growth that occurs upon EWMM exposure.

A further major alteration in expression was seen for motility, as the genes associated with flagella biosynthesis and chemotaxis were subject to repression (Table 8). Flagella-mediated motility 


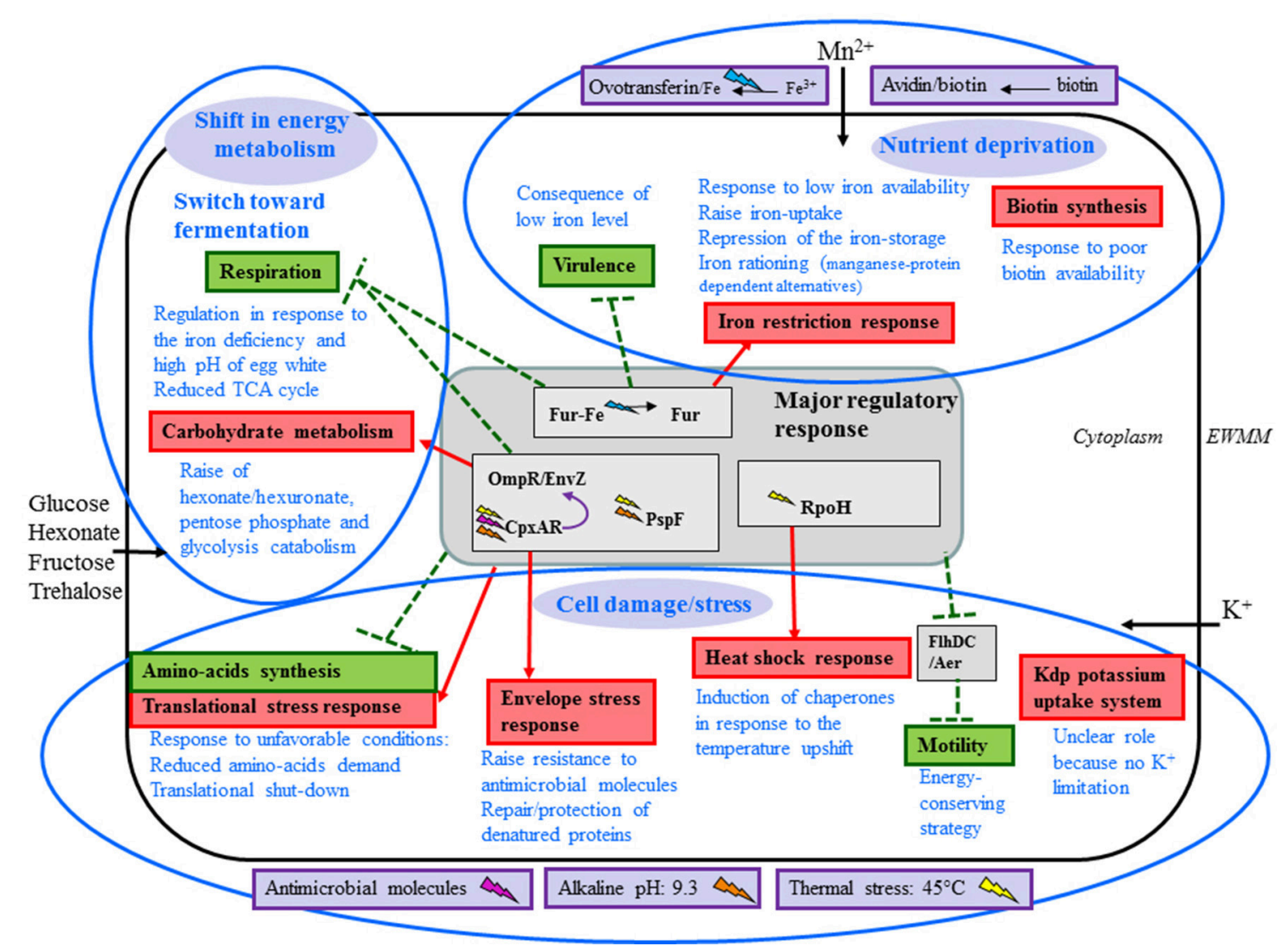

FIGURE 2 | Summary of physiological response of S. Enteritidis to egg white exposure. Blue elipses are used to indicate the three major responses elicited by egg white. The central gray box represents the major genetic regulatory responses. Boxes in purple are the egg white factors that are interpreted as having a clear impact on S. Enteritidis under the conditions employed here. Systems induced and repressed are indicated in red and green, respectively. Physiological responses are indicated in blue text. Black arrows indicate solute uptake suggested to be triggered by egg white exposure. Red arrows and green broken lines indicate, respectively, activation (red) and repression (green) by corresponding regulators: the origin of the arrow indicates the regulator involved (origins located in the central gray box indicate that all associated regulators are involved). Lighting symbols represent the stimuli that activate regulator responses: pink for antimicrobial molecules, orange for alkaline stress, yellow for thermal stress and blue for low iron conditions.

is transcriptionally controlled in response to multiple stresses including heat-shock ( $\mathrm{RpoH}$ dependent), $\mathrm{pH}$ change (CpxAR dependent), envelope stress (OmpR/EnvZ, CpxAR and PspF dependent) and low iron content (Fur dependent) (Shin and Park, 1995; Prüß et al., 2003; Lloyd et al., 2004; Jovanovic et al., 2006; Raivio et al., 2013), which are all of relevance to the conditions experienced upon EWMM exposure, as indicated by the transcriptomics data. The down-regulation of flagella/motility genes is consistent with AFM (Atomic Force Microscopy) observation in EWMM showing lack of flagella at 30 and $45^{\circ} \mathrm{C}$ in E. coli (Jan et al., 2013). Repression of motility genes at high $\mathrm{pH}$ (8.6) was also shown by Maurer et al. (2005), which matches the expression effects reported here. It should be stressed that some reports indicate that motility is a requirement for egg colonization by $S$. Enteritidis; non-motile $S$. Enteritidis mutants ( $f i C$ and $\operatorname{mot} A B$ ) are unable to grow in egg white or colonize eggs (Cogan et al., 2004), and a non-flagellated flgG mutant of $S$. Enteritidis showed a reduced survival in egg albumen (Gantois et al., 2008a). These observations suggest that the reduced expression of motility factors in EWMM, as observed here, might at least partly explain the inability of $S$. Enteritidis to propagate in this medium. The shutdown of flagella production and motility may represent an energy-conserving strategy since flagella motion is energy demanding (Zhao et al., 2007).

The reason for the induction of the $k d p$ system (Table 9) is unclear because $\mathrm{K}^{+}$levels in egg white medium are not limited ( $~ 36 \mathrm{mM}$ in egg white; Nys and Sauveur, 2004) and the osmolarity of egg white medium ( $\sim 240 \mathrm{mosm} / \mathrm{L}$; Alabdeh, 2012) is comparable to that of the pre-culture medium, TSB ( $320 \mathrm{mosm} / \mathrm{L}$; (Alabdeh, 2012). However, KdpD kinase senses intracellular rather than extracellular $\mathrm{K}^{+}$and $\mathrm{K}^{+}$is crucial for the regulation of intracellular $\mathrm{pH}$, as well as for the activity of several enzymes (Page and Di Cera, 2006). In the conditions used here (no extra-cellular $\mathrm{K}^{+}$limitation, no osmotic shock, alkaline $\mathrm{pH}$, physiological and metabolic adaptation to egg white conditions), Kdp activation probably reflects an attempt to alter cellular levels of $\mathrm{K}^{+}$in response to exposure to EWMM. 


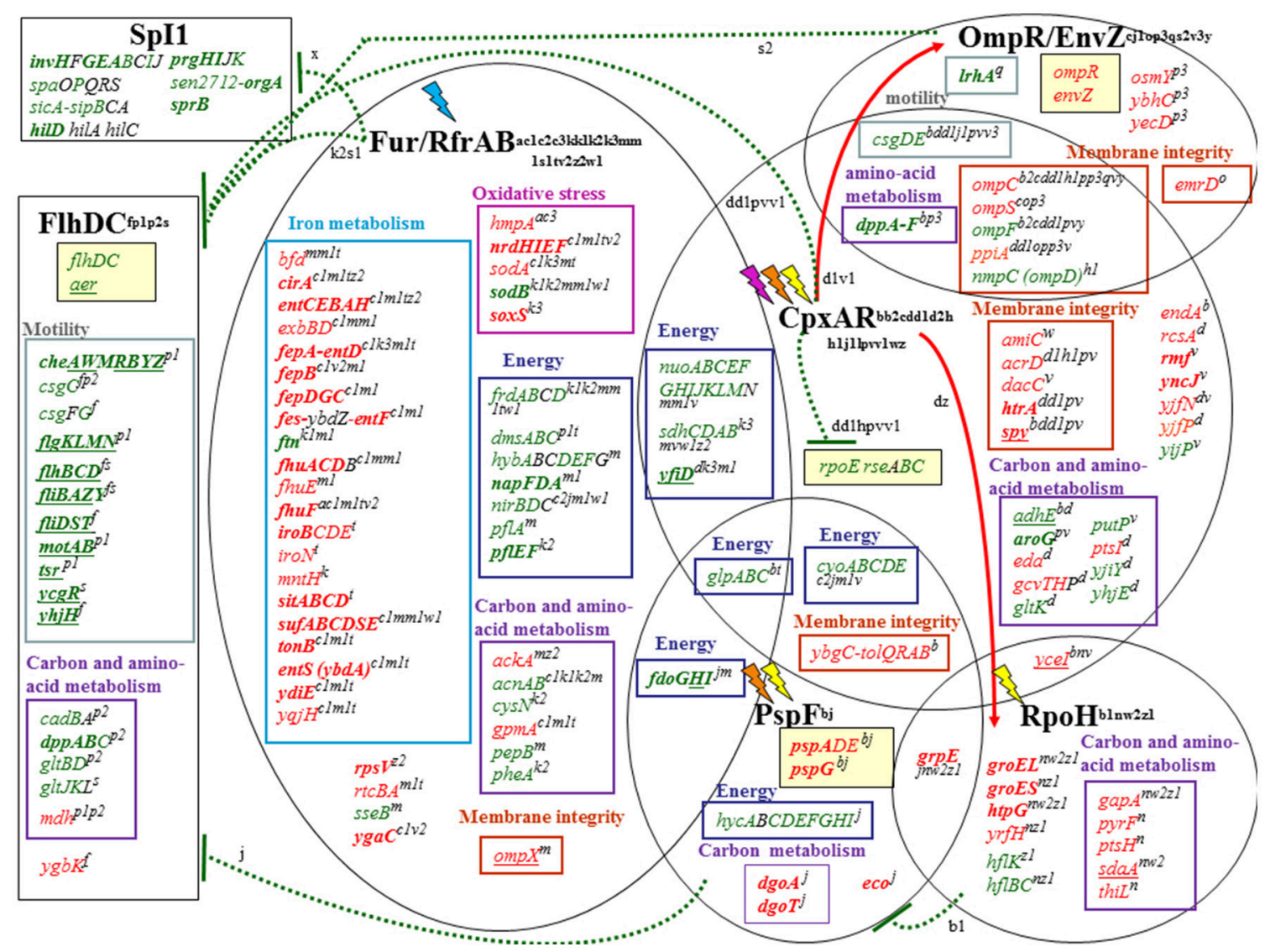

FIGURE 3 | Summary of the major global regulatory responses of S. Enteritidis to bacteriocidal egg white exposure. Each regulon is represented by black elipses and lighting symbols represent the stimuli that activate regulator responses: pink for antimicrobial molecules, orange for alkaline stress, yellow for thermal stress and blue for low iron conditions. Up-regulated, down-regulated and non-regulated genes are represented in red, green or black, respectively. Genes with a >fourfold change in expression are in bold. Genes underlined are identified as up or down regulated by alkaline pH (Maurer et al., 2005). Red arrows and green broken lines indicate, respectively, activation (red) and repression (green) by corresponding regulators: the origin of the arrows indicates the regulator involved. In each regulon, genes are grouped in boxes depending of the metabolic pathway to which they belong: iron metabolism (turquoise), oxidative stress (fuchsia), energy (dark blue), carbon and amino-acid metabolism (purple), motility (gray) and membrane integrity (orange). Genes previously reported to be regulated by the corresponding regulators are indicated by uppercase letters with the following designations: Brissette et al., 1991 [b1]; Stojiljkovic et al., 1994 [s1]; Crawford and Goldberg, 1998 [c3]; Danese and Silhavy, 1998 [d2]; Vassinova and Kozyrev, 2000 [v2]; Prüß et al., 2001 [p1]; D’Autréaux et al., 2002 [a]; De Wulf et al., 2002 [d]; Kehres et al., 2002 [k]; Oshima et al., 2002 [o]; McHugh et al., 2003 [m1]; Prüß et al., 2003 [p2]; Humphreys et al., 2004 [h]; Batchelor et al., 2005 [b2]; Jubelin et al., 2005 [11]; Massé et al., 2005 [m]; Stafford et al., 2005 [s]; Vianney, 2005 [v3]; Zhao et al., 2005 [z1]; Zhang et al., 2005 [z2]; Dorel et al., 2006 [d1]; Jovanovic et al., 2006 [j]; Nonaka et al., 2006 [n]; Wade et al., 2006 [w2]; Yoshida et al., 2006 [y]; Zahrl et al., 2006 [z]; Chen et al., 2007 [c1]; Bury-Moné et al., 2009 [b]; Price and Raivio, 2009 [p]; Perkins et al., 2009 [p3]; De la Cruz and Calva, 2010 [c]; Hu et al., 2011 [h1]; Kumar and Shimizu, 2011 [k3]; Weatherspoon-Griffin et al., 2011 [w]; Troxell et al., 2011 [t]; Teixidó et al., 2011 [x]; Lin et al., 2012 []; Kim and Kwon, 2013a [k1]; Kim and Kwon, 2013b [k2]; Samanta et al., 2013 [s2]; Raivio et al., 2013 [v]; Wright et al., 2013 [w1]; Calderón et al., 2014 [c2]; Fitzgerald et al., 2014 [f]; Quinn et al., 2014 [q]; Raivio, 2014 [v1].

\section{Shift in Energy Metabolism and Catabolism}

The expression data also provide evidence for a major switch in energy-generation mode since most of the genes involved in respiration were repressed (Table 10). It is likely that their repression is largely caused by the low-iron conditions of EWMM as part of an iron-rationing response induced to reduce the demand for iron. The iron-rationing response is controlled indirectly by Fur through RfrA and RfrB in Salmonella (RyhB in E. coli) and largely functions to repress genes encoding ironcontaining proteins in reaction to low iron conditions (McHugh et al., 2003; Massé et al., 2005; Yang et al., 2013). Thus, the observed down regulation of the genes listed in Table $\mathbf{1 0}$ appears, in part at least, to represent an attempt by $S$. Enteritidis to reprioritize cellular iron deployment. The down-regulation of these genes is likely to also include regulatory effects mediated by CpxAR (envelope and/or pH stress) and PspF (pmf dissipation). These effects correlate well with the low iron availability, high $\mathrm{pH}$ and membrane-disruption capacity associated with egg white (Baron et al., 2016).

The apparent loss of respiratory capacity was accompanied by other expression changes suggesting modifications in energy generation and catabolic processes (Table 11). The major induction of the 15 genes associated with hexonate and hexuronate metabolism was unexpected and is unexplained. 
These systems have not been previously reported to possess any role in egg white survival, nor have they been shown to be up-regulated by egg white exposure or to be subject to co-regulation. The main carbohydrate present in egg white is glucose ( $98 \%$ of total sugar; $0.4-0.5 \% \mathrm{w} / \mathrm{v})$, with lower levels of other sugars which include mannose, galactose, arabinose, xylose, ribose and deoxyribose (Guérin-Dubiard et al., 2010). As hexonates and hexuronates are not reported to be present within egg white, the identity of the inducer (and its source) responsible for dgoRKADT, uxuAB-uxaC and SEN1433-6 up-regulation is unclear, although evidently these genes are not subject to any substantial catabolite repression since induction is observed despite the high glucose levels in egg white. In summary, the clear implication of these data is that during incubation in egg white, S. Enteritidis is exposed to hexonates and/or hexuronates, or a related compound, which results in co-induction of the dgo, uxu and SEN1433-6 gene sets that potentially represent a novel regulon. Since egg white lacks any of these organic acids, the most likely reason for the induction observed would appear to be the release of an endogenous inducer from $S$. Enteritidis, possibly in response to cell envelope damage. However, further experiments are required in order to clarify how EWMM exposure results in the induction of this set of genes and whether hexonate/hexuronate metabolism plays any role in egg white survival.

Increased glucose and hexonate/hexuronate catabolic capacity, increased uptake of carbohydrate and glycolysis along with serine breakdown via the One-Carbon pathway (induction of genes involved in the degradation of serine, glycine and threonine to pyruvate: $g c v H T, s d a A, g l y A, k b l, t d h$; $\operatorname{serB}$; Table 11) would be anticipated to boost ATP production through substrate-level phosphorylation which could at least partly compensate for loss of respiratory capacity and reduced expression of respiratory components.

The combined up-regulation of glycolysis with the down regulation of both the TCA cycle and respiration, as indicated above, is suggestive of a shift in energy metabolism away from respiration and toward fermentation. Indeed, the acetate kinase $(a c k A)$ and ethanol dehydrogenase $(a d h P)$ genes encoding mixed-acid fermentation enzymes are induced, supporting this notion. It is possible that the resulting accumulation of organic acids contributes to alkaline $\mathrm{pH}$ adaptation (Stancik et al., 2002; Yohannes et al., 2004; Slonczewski et al., 2009).

In conclusion, the gene expression response of $S$. Enteritidis to EWMM exposure at $45^{\circ} \mathrm{C}$ reveals three major effects: nutrient deprivation; cell damage/stress; and a shift in energy metabolism and catabolism, as summarized in Figure 2.

\section{Comparison of Transcriptomic and Mutation Data}

There is a general agreement that the key processes in egg white defense are iron deficiency (through iron chelation by ovotransferrin) and disruption of bacterial membranes by antimicrobial compounds (lysozyme, ovotransferrin, and various other antimicrobial molecules) (Clavijo et al., 2006; Kang et al.,
2006; Baron et al., 2016). Previous mutagenesis-based studies revealed a number of specific cell functions required for $S$. Enteritidis to overcome egg white defenses (Cogan et al., 2001; Lu et al., 2003; Kang et al., 2006; Gantois et al., 2008a, 2009b; Raspoet et al., 2014). These include sugar, amino acid and nucleic acid metabolism, cell envelope biogenesis and maintenance (including LPS biosynthesis), motility, iron transport, DNA synthesis and repair, stress responses, invasion and pathogenicity (Cogan et al., 2001; Lu et al., 2003; Clavijo et al., 2006; Kang et al., 2006; Gantois et al., 2008b, 2009a; Baron et al., 2016 for review). However, such mutagenesis studies do not provide a comprehensive view of the combined and relative effects that egg white exerts upon $S$. Enteritidis since the numbers of genes identified in each individual study are limited and the experimental conditions employed are distinct for each study (Baron et al., 2016 for review). In contrast, our investigation of the global expression response of $S$. Enteritidis to egg white provides a complete genome-wide view of the complex physiological response of this pathogen to egg white-induced bactericide under specific conditions. The three major alterations in cell function (Figure 2) appear to well match the requirements of $S$. Enteritidis when challenged with egg white.

However, the gene sets showing major expression changes in the bactericidal conditions of EWMM are not a precise match for those highlighted by previous mutagenesis approaches although they do compare well with the corresponding functional-gene categories identified in earlier work, and thus the data presented here can be considered to generally support previous findings. One notable distinction is the failure to observe any modulation of genes related to LPS biosynthesis. Gantois et al. (2009b) showed that the $r f b H$ gene, involved in lipopolysaccharide biosynthesis, is essential for survival at $42^{\circ} \mathrm{C}$, and Raspoet et al. (2014) identified 16 lipopolysaccharide biosynthesis genes required for survival in egg white at $42^{\circ} \mathrm{C}$ for $24 \mathrm{~h}$. This discrepancy likely relates to differences in conditions (e.g., temperature and incubation times) and experimental approaches employed, e.g., expression vs. survival.

\section{Insight into the Bactericidal Action of Egg White}

There are a number of bactericidal and bacteriostatic factors combined within egg white that operate together to generate a highly effective antibacterial cocktail. This amalgamation of components can be expected to exert a mutually-dependent, combinatorial antibacterial influence. Nutrient deprival should act to restrict pathogen growth and thus limit capacity to react to lethal stresses that induce envelope disruption. A key component of egg white defense, illustrated in this work, is temperature. Thus, S. Enteritidis suffers bacteriostasis upon exposure to egg white at moderate temperature $\left(30^{\circ} \mathrm{C}\right)$ but is lysed at $45^{\circ} \mathrm{C}$ (although not in TSB) showing that the lytic activity of egg white is markedly enhanced by temperature. This observation suggests that the lethal antibacterial egg white components affecting $S$. Enteritidis survival operate optimally at $\sim 45^{\circ} \mathrm{C}$, a feature possibly related to increased bacterial membrane fluidity at higher temperature (Los and Murata, 2004). 
A summary of the physiological responses and major regulatory effects suggested by the transcriptional data is shown in Figures 2, 3. The regulators that appear to have the greatest influence on expression in EWMM at $45^{\circ} \mathrm{C}$ are Fur, $\mathrm{RpoH}, \mathrm{PspF}$, OmpR/EnvZ, CpxAR, and FlhDC. The environmental and egg white factors to which these regulators respond are low iron content (ovotransferrin mediated), unfolded proteins (induced by high temperature, alkaline $\mathrm{pH}$ ), pmf dissipation and envelope stress (egg white membrane disruption, alkaline $\mathrm{pH}$ ). The regulatory responses are thus an excellent representation of the environmental conditions provided by EWMM at $45^{\circ} \mathrm{C}$. These regulons are highly interconnected (Figure 3). For instance, CpxAR modulates the action of various regulators including OmpR/EnvZ, FlhDC, RpoE and RpoH (Dorel et al., 2006; Raivio, 2014). Moreover, Fur, PspF and OmpR/EnvZ regulate FlhDC (Stojiljkovic and Hantke, 1992; Campoy et al., 2002; Jovanovic et al., 2006; Samanta et al., 2013) and PspF is negatively regulated by $\mathrm{RpoH}$ involved in the heat shock response (Brissette et al., 1991). Some of the differentially-regulated genes listed above are subject to joint control by more than one of the transcription factors highlighted in Figure 3.

The transcriptomic analysis performed here shows that incubation in EWMM at $45^{\circ} \mathrm{C}$ provokes a major modification of $S$. Enteritidis physiology that can be presumed to raise capacity to withstand the harmful effects imposed. However, although $S$. Enteritidis displays strong resistance to egg white, it surrcumbs to its bacteriocidal influences at temperatures of $\geq 42^{\circ} \mathrm{C}$ (Alabdeh et al., 2011). The temperature condition employed here $\left(45^{\circ} \mathrm{C}\right)$ matches with that recommended for the French patent (Liot and Anza, 1996) that decribes a highly-efficient liquid egg white microbial stabilization process. This temperature is similar to that encountered naturally during egg formation in the hen genital tract $\left(42^{\circ} \mathrm{C}\right)$, and during hatching $\left(\sim 42^{\circ} \mathrm{C}\right)$. Interestingly, a previous study (Keller et al., 1995) showed that although $S$. Enteritidis infection of the reproductive organs causes significant contamination of eggs prior to oviposition, the level of

\section{REFERENCES}

Abdel-Hamid, A. M., and Cronan, J. E. (2007). Coordinate expression of the acetyl coenzyme a carboxylasegenes, Accb and Accc, is necessary for normal regulation of biotin synthesis in Escherichia coli. J. Bacteriol. 189, 369-376. doi: 10.1128/JB.01373-06

Aguilera, O., Quiros, L. M., and Fierro, J. F. (2003). Transferrins selectively cause ion efflux through bacterial and artificial membranes. FEBS Lett. 548, 5-10. doi: 10.1016/S0014-5793(03)00719-1

Alabdeh, M. (2012). Activité Antimicrobienne du Blanc D'oeuf de Poule: Identification des Systèmes Moléculaires et des Cibles Physiologiques Impliquées. Thesis, University of Rennes, Rennes.

Alabdeh, M., Lechevalier, V., Nau, F., Gautier, M., Cochet, M.-F., Gonnet, F., et al. (2011). Role of incubation conditions and protein fraction on the antimicrobial activity of egg white against Salmonella Enteritidis and Escherichia coli. J. Food Prot. 74, 24-31. doi: 10.4315/0362-028X.JFP-10-157

Andrews, S. C. (2011). Making DNA without iron - induction of a manganese-dependent ribonucleotide reductase in response to iron starvation. Mol. Microbiol. 80, 286-289. doi: 10.1111/j.1365-2958.2011. 07594.x contamination is greatly decreased after laying. It was suggested that this is due to the enhanced bacteriocidal effects of egg white during the full egg formation phase in the oviduct (over $21 \mathrm{~h}$ ), which would be promoted by the temperature of the hen oviduct $\left(42^{\circ} \mathrm{C}\right)$. This observation provides further evidence that the precise environmental conditions of egg white are instrumental for achieving optimal antibacterial activity and that the innate immunity of the egg white is "designed" for maximum effect according to the environmental parameters that prevail during egg formation and hatching.

\section{AUTHOR CONTRIBUTIONS}

MA: Planning and carrying out experiments, analysis and interpretation of the microarray data, drafting a part of the results sections. MC: Planning and carrying out experiments, analysis of the microarray and RT-PCR data, drafting the materials and methods and references sections. FB, SB, SJ, MG, FN, CG, SA: Conception and design of the work, design of the experiments, data interpretation, drafting parts of the results section or discussion (according to the specific specialty of each author: microbiology, molecular biology, biochemistry, iron metabolism). In addition, FB, SB, SA critically revised the entire manuscript for important intellectual content. All authors: final approval; agreement for accountability.

\section{FUNDING}

MA received funding from the French Government.

\section{ACKNOWLEDGMENTS}

We thank Jean-Yves Coppée, Marie-Agnès Dillies, and Caroline Proux from transcriptome and epigenome (PF2) platform of Pasteur Institute for microarray experiments, statistical analysis and helpful discussion.

Andrews, S. C., Robinson, A. K., and Rodriguez-Quinones, F. (2003). Bacterial iron homeostasis. Fems Microbiol. Rev. 27, 215-237. doi: 10.1016/S0168-6445 (03)00055-X

Anjem, A., Varghese, S., and Imlay, J. A. (2009). Manganese import is a key element of the OxyR response to hydrogen peroxide in Escherichia coli. Mol. Microbiol. 72, 844-858. doi: 10.1111/j.1365-2958.2009.06699.x

Appia-Ayme, C., Patrick, E., J. Sullivan, M., Alston, M. J., Field, S. J., AbuOun, M., et al. (2011). Novel inducers of the envelope stress response BaeSR in Salmonella Typhimurium: BaeR is critically required for tungstate waste disposal. PLoS ONE 6:e23713. doi: 10.1371/journal.pone.0023713

Arsène, F., Tomoyasu, T., and Bukau, B. (2000). The heat shock response of Escherichia coli. Int. J. Food Microbiol. 55, 3-9. doi: 10.1016/S0168-1605 (00)00206-3

Asha, H., and Gowrishankar, J. (1993). Regulation of kdp operon expression in Escherichia coli: evidence against turgor as signal for transcriptional control. J. Bacteriol. 175, 4528-4537. doi: 10.1128/jb.175.14.4528-4537.1993

Audrain, B., Ferrières, L., Zairi, A., Soubigou, G., Dobson, C., Coppée, J.-Y., et al. (2013). Induction of the Cpx envelope stress pathway contributes to Escherichia coli tolerance to antimicrobial peptides. Appl. Environ. Microbiol. 79, 7770-7779. doi: 10.1128/AEM.02593-13 
Banks, J. G., Board, R. G., and Sparks, N. H. (1986). Natural antimicrobial systems and their potential in food preservation of the future. Biotechnol. Appl. Biochem. $8,103-147$.

Baron, F. (2010). "Qualité microbiologique de l'oeuf," in Science et Technologie de L'oeuf, ed A. Lavoisier (Paris: Lavoisier), 315-350.

Baron, F., Cochet, M. F., Ablain, W., Grosset, N., Madec, M. N., Gonnet, F., et al. (2006). Rapid and cost-effective method for microorganism enumeration based on miniaturization of the conventional plate-counting technique. Lait 86, 251-257. doi: 10.1051/lait:2006005

Baron, F., Gautier, M., and Brule, G. (1997). Factors involved in the inhibition of growth of Salmonella Enteritidis in liquid egg white. J. Food Prot. 60, 1318-1323. doi: 10.4315/0362-028X-60.11.1318

Baron, F., Nau, F., Guérin-Dubiard, C., Bonnassie, S., Gautier, M., Andrews, S. C., et al. (2016). Egg white versus Salmonella Enteritidis! A harsh medium meets a resilient pathogen. Food Microbiol. 53(Part B), 82-93. doi: 10.1016/j.fm.2015.09.009

Batchelor, E., Walthers, D., Kenney, L. J., and Goulian, M. (2005). The Escherichia coli CpxA-CpxR envelope stress response system regulates expression of the porins OmpF and OmpC. J. Bacteriol. 187, 5723-5731. doi: 10.1128/JB.187.16.5723-5731.2005

Beckett, D. (2007). Biotin sensing: universal influence of biotin status on transcription. Annu. Rev. Genet. 41, 443-464. doi: 10.1146/annurev.genet. 41.042007.170450

Benjamini, Y., and Yekutieli, D. (2001). The control of the false discovery rate in multiple testing under dependency. Ann. Stat. 29, 1165-1188. doi: 10.1214/aos/1013699998

Bjarnason, J., Southward, C. M., and Surette, M. G. (2003). Genomic profiling of iron-responsive genes in Salmonella enterica serovar Typhimurium by high-throughput screening of a random promoter library. J. Bacteriol. 185, 4973-4982. doi: 10.1128/JB.185.16.4973-4982.2003

Blumer, C. (2005). Regulation of type 1 fimbriae synthesis and biofilm formation by the transcriptional regulator LrhA of Escherichia coli. Microbiology 151, 3287-3298. doi: 10.1099/mic.0.28098-0

Bradshaw, J. G., Shah, D. B., Forney, E., and Madden, J. M. (1990). Growth of Salmonella Enteritidis in yolk of shell eggs from normal and seropositive hens. J. Food Prot. 53, 1033-1036. doi: 10.4315/0362-028X-53.12.1033

Brissette, J. L., Russel, M., Weiner, L., and Model, P. (1990). Phage shock protein, a stress protein of Escherichia coli. Proc. Natl. Acad. Sci. U.S.A. 87, 862-866. doi: 10.1073/pnas.87.3.862

Brissette, J. L., Weiner, L., Ripmaster, T. L., and Model, P. (1991). Characterization and sequence of the Escherichia coli stress-induced $p s p$ operon. J. Mol. Biol. 220, 35-48. doi: 10.1016/0022-2836(91)90379-K

Bury-Moné, S., Nomane, Y., Reymond, N., Barbet, R., Jacquet, E., Imbeaud, S., et al. (2009). Global analysis of extracytoplasmic stress signaling in Escherichia coli. PLoS Genet. 5:e1000651. doi: 10.1371/journal.pgen.1000651

Calderón, P. F., Morales, E. H., Acuña, L. G., Fuentes, D. N., Gil, F., Porwollik, S., et al. (2014). The small RNA RyhB homologs from Salmonella Typhimurium participate in the response to S-nitrosoglutathione-induced stress. Biochem. Biophys. Res. Commun. 450, 641-645. doi: 10.1016/j.bbrc.2014. 06.031

Campoy, S., Jara, M., Busquets, N., de Rozas, A. M. P., Badiola, I., and Barbé, J. (2002). Intracellular cyclic AMP concentration is decreased in Salmonella Typhimurium fur mutants. Microbiology 148, 1039-1048. doi: 10.1099/00221287-148-4-1039

Cascales, E., Gavioli, M., Sturgis, J. N., and Lloubès, R. (2000). Proton motive force drives the interaction of the inner membrane TolA and outer membrane Pal proteins in Escherichia coli. Mol. Microbiol. 38, 904-915. doi: 10.1046/j.1365-2958.2000.02190.x

Chen, J., Thesmar, H. S., and Kerr, W. L. (2005). Outgrowth of Salmonellae and the physical property of albumen and vitelline membrane as influenced by egg storage conditions. J. Food Prot. 68, 2553-2558. doi: 10.4315/0362-028X-68.12.2553

Chen, S., Cui, S., McDermott, P. F., Zhao, S., White, D. G., Paulsen, I., et al. (2007). Contribution of target gene mutations and efflux to decreased susceptibility of Salmonella enterica serovar Typhimurium to fluoroquinolones and other antimicrobials. Antimicrob. Agents Chemother. 51, 535-542. doi: 10.1128/AAC. 00600-06
Christensen, S. K., Mikkelsen, M., Pedersen, K., and Gerdes, K. (2001). RelE, a global inhibitor of translation, is activated during nutritional stress. Proc. Natl. Acad. Sci. U.S.A. 98, 14328-14333. doi: 10.1073/pnas.251327898

Claret, L., and Hughes, C. (2002). Interaction of the atypical prokaryotic transcription activator FlhD2C2 with early promoters of the flagellar gene hierarchy. J. Mol. Biol. 321, 185-199. doi: 10.1016/S0022-2836(02) 00600-9

Clavijo, R. I., Loui, C., Andersen, G. L., Riley, L. W., and Lu, S. (2006). Identification of genes associated with survival of Salmonella enterica serovar Enteritidis in chicken egg albumen. Appl. Environ. Microbiol. 72, 1055-1064. doi: 10.1128/AEM.72.2.1055-1064.2006

Clay, C. E., and Board, R. G. (1991). Growth of Salmonella Enteritidis in artificially contaminated hens' shell eggs. Epidemiol. Infect. 106, 271-281. doi: $10.1017 /$ S095026880004841X

Cogan, T. A., Domingue, G., Lappin-Scott, H. M., Benson, C. E., Woodward, M. J., and Humphrey, T. J. (2001). Growth of Salmonella Enteritidis in artificially contaminated eggs: the effects of inoculum size and suspending media. Int. J. Food Microbiol. 70, 131-141. doi: 10.1016/S0168-1605(01)00540-2

Cogan, T. A., Jørgensen, F., Lappin-Scott, H. M., Benson, C. E., Woodward, M. J., and Humphrey, T. J. (2004). Flagella and curli fimbriae are important for the growth of Salmonella enterica serovars in hen eggs. Microbiology 150, 1063-1071. doi: 10.1099/mic.0.26791-0

Cooper, R. A. (1978). The utilisation of D-galactonate and D-2-oxo-3deoxygalactonate by Escherichia coli K-12. Biochemical and genetical studies. Arch. Microbiol. 118, 199-206. doi: 10.1007/BF00415730

Crawford, M. J., and Goldberg, D. E. (1998). Regulation of the Salmonella Typhimurium flavohemoglobin gene. new pathway for bacterial gene expression in response to nitric oxide. J. Biol. Chem. 273, 34028-34032. doi: $10.1074 /$ jbc.273.51.34028

Cronan, J. E. (1996). "Biosynthesis of membrane lipids," in Escherichia coli and Salmonella Cellular and Molecular Biology (Washington, DC: ASM Press), 612-636.

Danese, P. N., and Silhavy, T. J. (1998). CpxP, a stress-combative member of the Cpx regulon. J. Bacteriol. 180, 831-839.

Darwin, A. J. (2005). The phage-shock-protein response: The Psp response. Mol. Microbiol. 57, 621-628. doi: 10.1111/j.1365-2958.2005.04694.x

D'Autréaux, B., Touati, D., Bersch, B., Latour, J.-M., and Michaud-Soret, I. (2002). Direct inhibition by nitric oxide of the transcriptional ferric uptake regulation protein via nitrosylation of the iron. Proc. Natl. Acad. Sci. U.S.A. 99, 16619-16624. doi: 10.1073/pnas.252591299

Davidson, A. L., and Chen, J. (2004). ATP-Binding cassette transporters in bacteria. Annu. Rev. Biochem. 73, 241-268. doi: 10.1146/annurev. biochem.73.011303.073626

De la Cruz, M. Á., and Calva, E. (2010). The complexities of porin genetic regulation. J. Mol. Microbiol. Biotechnol. 18, 24-36. doi: 10.1159/0002 74309

De Vylder, J., Raspoet, R., Dewulf, J., Haesebrouck, F., Ducatelle, R., and Van Immerseel, F. (2013). Salmonella Enteritidis is superior in egg white survival compared with other Salmonella serotypes. Poult. Sci. 92, 842-845. doi: 10.3382/ps.2012-02668

De Wulf, P., McGuire, A. M., Liu, X., and Lin, E. C. C. (2002). Genomewide profiling of promoter recognition by the two-component response regulator CpxR-P in Escherichia coli. J. Biol. Chem. 277, 26652-26661. doi: 10.1074/jbc.M203487200

Delcour, A. H. (2009). Outer membrane permeability and antibiotic resistance. Biochim. Biophys. Acta BBA 1794, 808-816. doi: 10.1016/j.bbapap.2008.11.005

Dorel, C., Lejeune, P., and Rodrigue, A. (2006). The Cpx system of Escherichia coli, a strategic signaling pathway for confronting adverse conditions and for settling biofilm communities? Res. Microbiol. 157, 306-314. doi: $10.1016 /$ j.resmic.2005.12.003

Dubrac, S., and Touati, D. (2000). Fur positive regulation of iron superoxide dismutase in Escherichia coli: functional analysis of the sodB promoter. J. Bacteriol. 182, 3802-3808. doi: 10.1128/JB.182.13.3802-38 08.2000

Dubrac, S., and Touati, D. (2002). Fur-mediated transcriptional and posttranscriptional regulation of FeSOD expression in Escherichia coli. Microbiology 148, 147-156. doi: 10.1099/00221287-148-1-147 
EFSA BIOHAZ Panel (European Food Safety Autority Panel on Biological Hazards) (2014). Scientific Opinion on the public health risks of table eggs due to deterioration and development of pathogens. EFSA J. 3782, 1-147. doi: $10.2903 /$ j.efsa.2014.3782

Epstein, W. (2003). The roles and regulation of potassium in bacteria. Prog. Nucleic Acid Res. Mol. Biol. 75, 293-320. doi: 10.1016/S0079-6603(03)75008-9

Evans, K. L., Kannan, S., Li, G., Pedro, M. A., and de Young, K. D. (2013). Eliminating a set of four penicillin binding proteins triggers the Rcs phosphorelay and Cpx stress responses in Escherichia coli. J. Bacteriol. 195, 4415-4424. doi: 10.1128/JB.00596-13

Farris, C., Sanowar, S., Bader, M. W., Pfuetzner, R., and Miller, S. I. (2010). Antimicrobial peptides activate the Rcs regulon through the outer membrane lipoprotein RcsF. J. Bacteriol. 192, 4894-4903. doi: 10.1128/JB.00505-10

Fitzgerald, D. M., Bonocora, R. P., and Wade, J. T. (2014). Comprehensive mapping of the Escherichia coli flagellar regulatory network. PLoS Genet. 10:e1004649. doi: 10.1371/journal.pgen.1004649

Franchini, A. G. (2006). Global gene expression in Escherichia coli K-12 during short-term and long-term adaptation to glucose-limited continuous culture conditions. Microbiology 152, 2111-2127. doi: 10.1099/mic.0.28939-0

Gantois, I., Ducatelle, R., Pasmans, F., Haesebrouck, F., Gast, R., Humphrey, T. J., et al. (2009a). Mechanisms of egg contamination by Salmonella Enteritidis. FEMS Microbiol. Rev. 33, 718-738. doi: 10.1111/j.1574-6976.2008.00161.x

Gantois, I., Ducatelle, R., Pasmans, F., Haesebrouck, F., and Immerseel, F. V. (2008a). Salmonella enterica serovar Enteritidis genes induced during oviduct colonization and egg contamination in laying hens. Appl. Environ. Microbiol. 74, 6616-6622. doi: 10.1128/AEM.01087-08

Gantois, I., Ducatelle, R., Pasmans, F., Haesebrouck, F., and Van Immerseel, F. (2009b). The Salmonella Enteritidis lipopolysaccharide biosynthesis gene $\mathrm{rbb}$ is required for survival in egg albumen. Zoonoses Public Health 56, 145-149. doi: 10.1111/j.1863-2378.2008.01195.x

Gantois, I., Eeckhaut, V., Pasmans, F., Haesebrouck, F., Ducatelle, R., and Immerseel, F. V. (2008b). A comparative study on the pathogenesis of egg contamination by different serotypes of Salmonella. Avian Pathol. 37, 399-406. doi: 10.1080/03079450802216611

Garibaldi, J. A. (1970). Role of microbial iron transport compounds in bacterial spoilage of eggs. Appl. Microbiol. 20, 558-60.

Gerdes, K., Christensen, S. K., and Løbner-Olesen, A. (2005). Prokaryotic toxin-antitoxin stress response loci. Nat. Rev. Microbiol. 3, 371-382. doi: 10.1038/nrmicro1147

Guan, J., Grenier, C., and Brooks, B. W. (2006). In vitro study of Salmonella Enteritidis and Salmonella Typhimurium definitive type 104: survival in egg albumen and penetration through the vitelline membrane. Poult. Sci. 85, 1678-1681. doi: 10.1093/ps/85.9.1678

Guérin-Dubiard, C., Anton, M., Gautron, J., Nys, Y., and Nau, F. (2010). "Composition de l'oeuf," in Science et Technologie de l'oeuf: De l'oeuf aux Ovoproduits Sciences et Techniques Agroalimentaires (Paris: Lavoisier), 1-169.

Guisbert, E., Yura, T., Rhodius, V. A., and Gross, C. A. (2008). Convergence of molecular, modeling, and systems approaches for an understanding of the Escherichia coli heat shock response. Microbiol. Mol. Biol. Rev. 72, 545-554. doi: 10.1128/MMBR.00007-08

Hagenmaier, S., Stierhof, Y.-D., and Henning, U. (1997). A new periplasmic protein of Escherichia coli which is synthesized in spheroplasts but not in intact cells. J. Bacteriol. 179, 2073-2076. doi: 10.1128/jb.179.6.2073-2076.1997

Hassani, A. S., Amirmozafari, N., and Ghaemi, A. (2009). Virulence increasing of Salmonella Typhimurium in Balb/c mice after heat-stress induction of phage shock protein A. Curr. Microbiol. 59, 446-450. doi: 10.1007/s00284-0099458-z

Hirakawa, H., Inazumi, Y., Masaki, T., Hirata, T., and Yamaguchi, A. (2005). Indole induces the expression of multidrug exporter genes in Escherichia coli. Mol. Microbiol. 55, 1113-1126. doi: 10.1111/j.1365-2958.2004.04449.x

Hosie, A. H., and Poole, P. S. (2001). Bacterial ABC transporters of amino acids. Res. Microbiol. 152, 259-270. doi: 10.1016/S0923-2508(01)01197-4

Hu, W. S., Chen, H.-W., Zhang, R.-Y., Huang, C.-Y., and Shen, C.-F. (2011). The expression levels of outer membrane proteins STM1530 and OmpD, which are influenced by the CpxAR and BaeSR two-component systems, play important roles in the ceftriaxone resistance of Salmonella enterica serovar Typhimurium. Antimicrob. Agents Chemother. 55, 3829-3837. doi: 10.1128/AAC.00216-11
Hughes, K. T., Gillen, K. L., Semon, M. J., and Karlinsey, J. E. (1993). Sensing structural intermediates in bacterial flagellar assembly by export of a negative regulator. Science 262, 1277-1280. doi: 10.1126/science.8235660

Humphrey, T. J., and Whitehead, A. (1993). Egg age and the growth of Salmonella Enteritidis PT4 in egg contents. Epidemiol. Infect. 111, 209-219. doi: $10.1017 /$ S0950268800056910

Humphreys, S., Rowley, G., Stevenson, A., Anjum, M. F., Woodward, M. J., Gilbert, S., et al. (2004). Role of the two-component regulator CpxAR in the virulence of Salmonella enterica serotype typhimurium. Infect. Immun. 72, 4654-4661. doi: 10.1128/IAI.72.8.4654-4661.2004

Ikeda, J. S., Janakiraman, A., Kehres, D. G., Maguire, M. E., and Slauch, J. M. (2005). Transcriptional regulation of sitABCD of Salmonella enterica serovar Typhimurium by MntR and Fur. J. Bacteriol. 187, 912-922. doi: 10.1128/JB.187.3.912-922.2005

Jan, S., Baron, F., Alabdeh, M., Chaari, W., Grosset, N., Cochet, M.-F., et al. (2013). Biochemical and micrographic evidence of Escherichia coli membrane damage during incubation in egg white under bactericidal conditions. J. Food Prot. 76, 1523-1529. doi: 10.4315/0362-028X.JFP-12-418

Joly, N., Engl, C., Jovanovic, G., Huvet, M., Toni, T., Sheng, X., et al. (2010). Managing membrane stress: the phage shock protein (Psp) response, from molecular mechanisms to physiology. FEMS Microbiol. Rev. 34, 797-827. doi: 10.1111/j.1574-6976.2010.00240.x

Jones, B. D. (2005). Salmonella invasion gene regulation: a story of environmental awareness. J. Microbiol. Seoul Korea 43 Spec No., 110-117.

Jovanovic, G., Lloyd, L. J., Stumpf, M. P. H., Mayhew, A. J., and Buck, M. (2006). Induction and function of the phage shock protein extracytoplasmic stress response in Escherichia coli. J. Biol. Chem. 281, 21147-21161. doi: 10.1074/jbc.M602323200

Jovanovic, G., and Model, P. (1997). PspF and IHF bind co-operatively in the psp promoter-regulatory region of Escherichia coli. Mol. Microbiol. 25, 473-481. doi: 10.1046/j.1365-2958.1997.4791844.x

Jubelin, G., Vianney, A., Beloin, C., Ghigo, J.-M., Lazzaroni, J.-C., Lejeune, P., et al. (2005). CpxR/OmpR interplay regulates curli gene expression in response to osmolarity in Escherichia coli. J. Bacteriol. 187, 2038-2049. doi: 10.1128/JB.187.6.2038-2049.2005

Kammler, M., Schön, C., and Hantke, K. (1993). Characterization of the ferrous iron uptake system of Escherichia coli. J. Bacteriol. 175, 6212-6219. doi: $10.1128 / \mathrm{jb}$.175.19.6212-6219.1993

Kang, H., Loui, C., Clavijo, R. I., Riley, L. W., and Lu, S. (2006). Survival characteristics of Salmonella enterica serovar Enteritidis in chicken egg albumen. Epidemiol. Infect. 134, 967. doi: 10.1017/S0950268806006054

Kehres, D. G., Janakiraman, A., Slauch, J. M., and Maguire, M. E. (2002). Regulation of Salmonella enterica serovar Typhimurium $\mathrm{mntH}$ transcription by $\mathrm{H}_{2} \mathrm{O}_{2}, \mathrm{Fe}^{2+}$, and $\mathrm{Mn}^{2+}$. J. Bacteriol. 184, 3151-3158. doi: $10.1128 / J B .184 .12 .3151-3158.2002$

Keller, L. H., Benson, C. E., Krotec, K., and Eckroade, R. J. (1995). Salmonella Enteritidis colonization of the reproductive tract and forming and freshly laid eggs of chickens. Infect. Immun. 63, 2443-2449.

Kim, J. N., and Kwon, Y. M. (2013a). Genetic and phenotypic characterization of the RyhB regulon in Salmonella Typhimurium. Microbiol. Res. 168, 41-49. doi: 10.1016/j.micres.2012.06.007

Kim, J. N., and Kwon, Y. M. (2013b). Identification of target transcripts regulated by small RNA RyhB homologs in Salmonella: RyhB-2 regulates motility phenotype. Microbiol. Res. 168, 621-629. doi: 10.1016/j.micres.2013. 06.002

Kleerebezem, M., Crielaard, W., and Tommassen, J. (1996). Involvement of stress protein PspA (phage shock protein A) of Escherichia coli in maintenance of the protonmotive force under stress conditions. EMBO J. 15, 162.

Ko, M., and Park, C. (2000). Two novel flagellar components and H-NS are involved in the motor function of Escherichia coli. J. Mol. Biol. 303, 371-382. doi: 10.1006/jmbi.2000.4147

Kohanski, M. A., Dwyer, D. J., Wierzbowski, J., Cottarel, G., and Collins, J. J. (2008). Mistranslation of membrane proteins and two-component system activation trigger antibiotic-mediated cell death. Cell 135, 679-690. doi: $10.1016 /$ j.cell.2008.09.038

Kumar, P., Arora, K., Lloyd, J. R., Lee, I. Y., Nair, V., Fischer, E., et al. (2012). Meropenem inhibits D,D-carboxypeptidase activity in Mycobacterium 
tuberculosis: peptidoglycan of M. tuberculosis. Mol. Microbiol. 86, 367-381. doi: 10.1111/j.1365-2958.2012.08199.x

Kumar, R., and Shimizu, K. (2011). Transcriptional regulation of main metabolic pathways of cyoA, cydB, fnr, and fur gene knockout Escherichia coli in C-limited and N-limited aerobic continuous cultures. Microb. Cell Factories 10, 1-15. doi: $10.1186 / 1475-2859-10-3$

Laubacher, M. E., and Ades, S. E. (2008). The Rcs phosphorelay is a cell envelope stress response activated by peptidoglycan stress and contributes to intrinsic antibiotic resistance. J. Bacteriol. 190, 2065-2074. doi: 10.1128/JB.01740-07

Lazzaroni, J. C., Germon, P., Ray, M.-C., and Vianney, A. (1999). The Tol proteins of Escherichia coli and their involvement in the uptake of biomolecules and outer membrane stability. FEMS Microbiol. Lett. 177, 191-197. doi: 10.1111/j.1574-6968.1999.tb13731.x

Lehnen, D., Blumer, C., Polen, T., Wackwitz, B., Wendisch, V. F., and Unden, G. (2002). LrhA as a new transcriptional key regulator of flagella, motility and chemotaxis genes in Escherichia coli. Mol. Microbiol. 45, 521-532. doi: 10.1046/j.1365-2958.2002.03032.x

Lin, X., Wang, C., Guo, C., Tian, Y., Li, H., and Peng, X. (2012). Differential regulation of OmpC and OmpF by AtpB in Escherichia coli exposed to nalidixic acid and chlortetracycline. J. Proteomics 75, 5898-5910. doi: 10.1016/j.jprot.2012.08.016

Liot, R., and Anza, L. (1996). Procédé de Traitement de blanc d'oeuf Liquide. French patent $n^{\circ} 9608356$, Paris.

Lloyd, L. J., Jones, S. E., Jovanovic, G., Gyaneshwar, P., Rolfe, M. D., Thompson, A., et al. (2004). Identification of a new member of the phage shock protein response in Escherichia coli, the phage shock protein G (PspG). J. Biol. Chem. 279, 55707-55714. doi: 10.1074/jbc.M408994200

Lock, J. L., and Board, R. G. (1992). Persistence of contamination of hens' egg albumen in vitro with Salmonella serotypes. Epidemiol. Infect. 108, 389-396. doi: $10.1017 /$ S095026880004989X

Los, D. A., and Murata, N. (2004). Membrane fluidity and its roles in the perception of environmental signals. Biochim. Biophys. Acta BBA 1666, 142-157. doi: 10.1016/j.bbamem.2004.08.002

Lu, S. W., Killoran, P. B., and Riley, L. W. (2003). Association of Salmonella enterica serovar Enteritidis YafD with resistance to chicken egg albumen. Infect. Immun. 71, 6734-6741. doi: 10.1128/IAI.71.12.6734-6741.2003

Lüders, S., Fallet, C., and Franco-Lara, E. (2009). Proteome analysis of the Escherichia coli heat shock response under steady-state conditions. Proteome Sci. 7, 36. doi: 10.1186/1477-5956-7-36

Lutz, R., and Bujard, H. (1997). Independent and tight regulation of transcriptional units in Escherichia coli via the LacR/O, the TetR/O and AraC/I1-I2 regulatory elements. Nucleic Acids Res. 25, 1203-1210. doi: 10.1093/nar/25.6.1203

Martin, J. E., and Imlay, J. A. (2011). The alternative aerobic ribonucleotide reductase of Escherichia coli, NrdEF, is a manganese-dependent enzyme that enables cell replication during periods of iron starvation. Mol. Microbiol. 80, 319-334. doi: 10.1111/j.1365-2958.2011.07593.x

Massé, E., and Gottesman, S. (2002). A small RNA regulates the expression of genes involved in iron metabolism in Escherichia coli. Proc. Natl. Acad. Sci. U.S.A. 99, 4620-4625. doi: 10.1073/pnas.032066599

Massé, E., Vanderpool, C. K., and Gottesman, S. (2005). Effect of RyhB small RNA on global iron use in Escherichia coli. J. Bacteriol. 187, 6962-6971. doi: 10.1128/JB.187.20.6962-6971.2005

Maurer, L. M., Yohannes, E., Bondurant, S. S., Radmacher, M., and Slonczewski, J. L. (2005). pH regulates genes for flagellar motility, catabolism, and oxidative stress in Escherichia coli K-12. J. Bacteriol. 187, 304-319. doi: 10.1128/JB.187.1.304-319.2005

McHugh, J. P., Rodriguez-Quinones, F., Abdul-Tehrani, H., Svistunenko, D. A., Poole, R. K., Cooper, C. E., et al. (2003). Global iron-dependent gene regulation in Escherichia coli - A new mechanism for iron homeostasis. J. Biol. Chem. 278, 29478-29486. doi: 10.1074/jbc.M303381200

Meisel, U., Holtje, J.-V., and Vollmer, W. (2003). Overproduction of inactive variants of the murein synthase $\mathrm{PBP} 1 \mathrm{~B}$ causes lysis in Escherichia coli. J. Bacteriol. 185, 5342-5348. doi: 10.1128/JB.185.18.5342-5348.2003

Messens, W., Duboccage, L., Grijspeerdt, K., Heyndrickx, M., and Herman, L. (2004). Growth of Salmonella serovars in hens' egg albumen as affected by storage prior to inoculation. Food Microbiol. 21, 25-32. doi: 10.1016/S0740-0020(03)00045-5
Miethke, M., Hou, J., and Marahiel, M. A. (2011). The siderophore-interacting protein $\mathrm{YqjH}$ acts as a ferric reductase in different iron assimilation pathways of Escherichia coli. Biochemistry 50, 10951-10964. doi: 10.1021/bi201517h

Mo, E., Peters, S. E., Willers, C., Maskell, D. J., and Charles, I. G. (2006). Single, double and triple mutants of Salmonella enterica serovar Typhimurium degP (htrA), degQ (hhoA) and degS (hhoB) have diverse phenotypes on exposure to elevated temperature and their growth in vivo is attenuated to different extents. Microb. Pathog. 41, 174-182. doi: 10.1016/j.micpath.2006.07.004

Mueller, O., Hahnenberger, K., Dittmann, M., Yee, H., Dubrow, R., Nagle, R., et al. (2000). A microfluidic system for high-speed reproducible DNA sizing and quantitation. Electrophoresis 21, 128-134. doi: 10.1002/(SICI)1522-2683(20000101)21:1<128::AID-ELPS128>3.0.CO;2-M

Murase, T., Holt, P. S., and Gast, R. K. (2005). Growth of Salmonella enterica serovar Enteritidis in albumen and yolk contents of eggs inoculated with this organism onto the vitelline membrane. J. Food Prot. 68, 718-721. doi: 10.4315/0362-028X-68.4.718

Naroditskaya, V., Schlosser, M. J., Fang, N. Y., and Lewis, K. (1993). An E. coli gene emrD is involved in adaptation to low energy shock. Biochem. Biophys. Res. Commun. 196, 803-809. doi: 10.1006/bbrc.1993.2320

Neilands, J. B. (1995). Siderophores: structure and function of microbial iron transport compounds. J. Biol. Chem. 270, 26723-26726. doi: $10.1074 /$ jbc. 270.45 .26723

Nikaido, H. (1996). Multidrug efflux pumps of gram-negative bacteria. J. Bacteriol. 178, 5853. doi: $10.1128 /$ jb.178.20.5853-5859.1996

Nonaka, G., Blankschien, M., Herman, C., Gross, C. A., and Rhodius, V. A. (2006). Regulon and promoter analysis of the E. coli heat-shock factor, $\sigma 32$, reveals a multifaceted cellular response to heat stress. Genes Dev. 20, 1776-1789. doi: 10.1101/gad.1428206

Nys, Y., and Sauveur, B. (2004). Valeur Nutritionnelle Des Oeufs. Available online at: http://prodinra.inra.fr/?locale=fr\#!ConsultNotice:77361 (Accessed February 17, 2016).

Oshima, T., Aiba, H., Masuda, Y., Kanaya, S., Sugiura, M., Wanner, B. L., et al. (2002). Transcriptome analysis of all two-component regulatory system mutants of Escherichia coli K-12. Mol. Microbiol. 46, 281-291. doi: 10.1046/j.1365-2958.2002.03170.x

Outten, F. W., Djaman, O., and Storz, G. (2004). A suf operon requirement for FeS cluster assembly during iron starvation in Escherichia coli. Mol. Microbiol. 52, 861-872. doi: 10.1111/j.1365-2958.2004.04025.x

Panina, E. M., Mironov, A. A., and Gelfand, M. S. (2001). Comparative analysis of FUR regulons in gamma-proteobacteria. Nucleic Acids Res. 29, 5195-5206. doi: 10.1093/nar/29.24.5195

Page, M.J., and Di Cera, E. (2006). Role of $\mathrm{Na}^{+}$and $\mathrm{K}^{+}$in enzyme function. Physiol. Rev. 86, 1049-1092. doi: 10.1152/physrev.00008.2006

Perkins, T. T., Davies, M. R., Klemm, E. J., Rowley, G., Wileman, T., James, K., et al. (2013). ChIP-seq and transcriptome analysis of the OmpR regulon of Salmonella enterica serovars Typhi and Typhimurium reveals accessory genes implicated in host colonization. Mol. Microbiol. 87, 526-538. doi: $10.1111 / \mathrm{mmi} .12111$

Perkins, T. T., Kingsley, R. A., Fookes, M. C., Gardner, P. P., James, K. D., Yu, L., et al. (2009). A strand-specific RNA-Seq analysis of the transcriptome of the typhoid Bacillus Salmonella typhi. PLoS Genet. 5:e1000569. doi: 10.1371/journal.pgen.1000569

Pratt, L. A., and Silhavy, T. J. (1996). The response regulator SprE controls the stability of RpoS. Proc. Natl. Acad. Sci. U.S.A. 93, 2488-2492. doi: 10.1073/pnas. 93.6.2488

Price, N. L., and Raivio, T. L. (2009). Characterization of the Cpx regulon in Escherichia coli strain MC4100. J. Bacteriol. 191, 1798-1815. doi: 10.1128/JB.00798-08

Prüß, B. M., Liu, X., Hendrickson, W., and Matsumura, P. (2001). FlhD/FlhCregulated promoters analyzed by gene array and lacZ gene fusions. FEMS Microbiol. Lett. 197, 91-97. doi: 10.1016/S0378-1097(01)00092-1

Prüß, B. M., Campbell, J. W., Dyk, T. K. V., Zhu, C., Kogan, Y., and Matsumura, P. (2003). FlhD/FlhC is a regulator of anaerobic respiration and the entnerdoudoroff pathway through induction of the methyl-accepting chemotaxis protein Aer. J. Bacteriol. 185, 534-543. doi: 10.1128/JB.185.2.534-543.2003

Quinn, H. J., Cameron, A. D. S., and Dorman, C. J. (2014). Bacterial regulon evolution: distinct responses and roles for the identical OmpR proteins of 
Salmonella Typhimurium and Escherichia coli in the acid stress response. PLoS Genet. 10:e1004215. doi: 10.1371/journal.pgen.1004215

Raffa, R. G., and Raivio, T. L. (2002). A third envelope stress signal transduction pathway in Escherichia coli. Mol. Microbiol. 45, 1599-1611. doi: $10.1046 / j .1365-2958.2002 .03112 . x$

Raivio, T. L. (2014). Everything old is new again: An update on current research on the Cpx envelope stress response. Biochim. Biophys. Acta BBA 1843, 1529-1541. doi: 10.1016/j.bbamcr.2013.10.018

Raivio, T. L., Laird, M. W., Joly, J. C., and Silhavy, T. J. (2000). Tethering of $\mathrm{CpxP}$ to the inner membrane prevents spheroplast induction of the Cpx envelope stress response. Mol. Microbiol. 37, 1186-1197. doi: 10.1046/j.1365-2958.2000.02074.x

Raivio, T. L., Leblanc, S. K. D., and Price, N. L. (2013). The Escherichia coli Cpx envelope stress response regulates genes of diverse function that impact antibiotic resistance and membrane integrity. J. Bacteriol. 195, 2755-2767. doi: 10.1128/JB.00105-13

Raivio, T. L., and Silhavy, T. J. (2001). Periplasmic stress and ECF sigma factors. Annu. Rev. Microbiol. 55, 591-624. doi: 10.1146/annurev.micro.55.1.591

Raspoet, R., Appia-Ayme, C., Shearer, N., Martel, A., Pasmans, F., Haesebrouck, F., et al. (2014). Microarray-based detection of Salmonella enterica serovar Enteritidis genes involved in chicken reproductive tract colonization. Appl. Environ. Microbiol. 80, 7710-7716. doi: 10.1128/AEM. 02867-14

Rodionov, D. A. (2003). Regulation of lysine biosynthesis and transport genes in bacteria: yet another RNA riboswitch? Nucleic Acids Res. 31, 6748-6757. doi: 10. 1093/nar/gkg900

Rosenberg, E. Y., Ma, D., and Nikaido, H. (2000). AcrD of Escherichia coli is an aminoglycoside efflux pump. J. Bacteriol. 182, 1754-1756. doi: 10.1128/JB.182.6.1754-1756.2000

Rosner, J. L., and Martin, R. G. (2013). Reduction of cellular stress by TolC-dependent efflux pumps in Escherichia coli indicated by BaeSR and CpxARP activation of spy in efflux mutants. J. Bacteriol. 195, 1042-1050. doi: $10.1128 /$ JB.01996-12

Rouvière, P. E., De Las Peñas, A., Mecsas, J., Lu, C. Z., Rudd, K. E., and Gross, C. A. (1995). rpoE, the gene encoding the second heat-shock sigma factor, sigma E, in Escherichia coli. EMBO J. 14, 1032-1042.

Ruzicková, V. (1994). Growth and survival of Salmonella Enteritidis in selected egg foods. Veterinární Med. 39, 187-195.

Samanta, P., Clark, E. R., Knutson, K., Horne, S. M., and Prüß, B. M. (2013). OmpR and RcsB abolish temporal and spatial changes in expression of $f h D$ in Escherichia coli biofilm. BMC Microbiol. 13:182. doi: 10.1186/1471-218013-182

Sauveur, B. (ed.). (1988). "Structure, composition et valeur nutritionnelle de l'oeuf," in Reproduction des Volailles et Production D'oeufs (Paris: Lavoisier), 347-374.

Sharma, C. M., Darfeuille, F., Plantinga, T. H., and Vogel, J. (2007). A small RNA regulates multiple $\mathrm{ABC}$ transporter mRNAs by targeting $\mathrm{C} / \mathrm{A}$-rich elements inside and upstream of ribosome-binding sites. Genes Dev. 21, 2804-2817. doi: 10.1101/gad.447207

Shin, S., and Park, C. (1995). Modulation of flagellar expression in Escherichia coli by acetyl phosphate and the osmoregulator OmpR. J. Bacteriol. 177, 4696-4702. doi: 10.1128/jb.177.16.4696-4702.1995

Slonczewski, J. L., Fujisawa, M., Dopson, M., and Krulwich, T. A. (2009). "Cytoplasmic pH measurement and homeostasis in Bacteria and Archaea," in Advances in Microbial Physiology, ed R. K. Poole (Washington: Academic Press), 1-317. Available online at: http://www.sciencedirect.com/science/ article/pii/S0065291109055015 (Accessed November 13, 2015).

Smyth, G. K. (2004). Linear models and empirical bayes methods for assessing differential expression in microarray experiments. Stat. Appl. Genet. Mol. Biol. 3, 1-25. doi: 10.2202/1544-6115.1027

Stafford, G. P., Ogi, T., and Hughes, C. (2005). Binding and transcriptional activation of non-flagellar genes by the Escherichia coli flagellar master regulator FlhD2C2. Microbiol. Read. Engl. 151, 1779-1788. doi: 10.1099/mic.0.27879-0

Stancik, L. M., Stancik, D. M., Schmidt, B., Barnhart, D. M., Yoncheva, Y. N., and Slonczewski, J. L. (2002). pH-dependent expression of periplasmic proteins and amino acid catabolism in Escherichia coli. J. Bacteriol. 184, 4246-4258. doi: 10.1128/JB.184.15.4246-4258.2002
Starosta, A. L., Lassak, J., Jung, K., and Wilson, D. N. (2014). The bacterial translation stress response. FEMS Microbiol. Rev. 38, 1172-1201. doi: 10.1111/1574-6976.12083

Stojiljkovic, I., Bäumler, A. J., and Hantke, K. (1994). Fur regulon in Gramnegative bacteria: identification and characterization of new iron-regulated Escherichia coli genes by a Fur titration assay. J. Mol. Biol. 236, 531-545. doi: 10.1006/jmbi.1994.1163

Stojiljkovic, I., and Hantke, K. (1992). Hemin uptake system of Yersinia enterocolitica: similarities with other TonB-dependent systems in Gramnegative bacteria. EMBO J. 11, 4359-4367.

Streit, W. R., and Entcheva, P. (2003). Biotin in microbes, the genes involved in its biosynthesis, its biochemical role and perspectives for biotechnological production. Appl. Microbiol. Biotechnol. 61, 21-31. doi: $10.1007 / \mathrm{s} 00253-002-1186-2$

Teixidó, L., Carrasco, B., Alonso, J. C., Barbé, J., and Campoy, S. (2011). Fur activates the expression of Salmonella enterica pathogenicity Island 1 by directly interacting with the hilD operator in vivo and in vitro. PLOS ONE 6:e19711. doi: 10.1371/journal.pone.0019711

Thede, G. L., Arthur, D. C., Edwards, R. A., Buelow, D. R., Wong, J. L., Raivio, T. L., et al. (2011). Structure of the periplasmic stress response protein CpxP. J. Bacteriol. 193, 2149-2157. doi: 10.1128/JB.01296-10

Tranter, H. S., and Board, R. G. (1984). The influence of incubation temperature and $\mathrm{pH}$ on the antimicrobial properties of hen egg albumen. J. Appl. Bacteriol. 56, 53-61. doi: 10.1111/j.1365-2672.1984.tb04696.x

Troxell, B., Fink, R. C., Porwollik, S., McClelland, M., and Hassan, H. M. (2011). The Fur regulon in anaerobically grown Salmonella enterica sv. Typhimurium: identification of new Fur targets. BMC Microbiol. 11:236. doi: 10.1186/1471-2180-11-236

Tschauner, K., Hörnschemeyer, P., Müller, V. S., and Hunke, S. (2014). Dynamic interaction between the CpxA sensor kinase and the periplasmic accessory protein CpxP mediates signal recognition in E. coli. PLoS ONE 9:e107383. doi: 10.1371/journal.pone.0107383

Vassinova, N., and Kozyrev, D. (2000). A method for direct cloning of fur-regulated genes: identification of seven new fur-regulated loci in Escherichia coli. Microbiology 146, 3171-3182. doi: 10.1099/00221287-14612-3171

Vianney, A. (2005). Escherichia coli tol and rcs genes participate in the complex network affecting curli synthesis. Microbiology 151, 2487-2497. doi: $10.1099 /$ mic. $0.27913-0$

Vines, E. D., Marolda, C. L., Balachandran, A., and Valvano, M. A. (2005). Defective O-antigen polymerization in tolA and pal mutants of Escherichia coli in response to extracytoplasmic stress. J. Bacteriol. 187, 3359-3368. doi: 10.1128/JB.187.10.3359-3368.2005

Wade, J. T., Roa, D. C., Grainger, D. C., Hurd, D., Busby, S. J. W., Struhl, K., et al. (2006). Extensive functional overlap between $\sigma$ factors in Escherichia coli. Nat. Struct. Mol. Biol. 13, 806-814. doi: 10.1038/nsmb1130

Walker, S. L., Sojka, M., Dibb-Fuller, M., and Woodward, M. J. (1999). Effect of $\mathrm{pH}$, temperature and surface contact on the elaboration of fimbriae and flagella by Salmonella serotype Enteritidis. J. Med. Microbiol. 48, 253-261. doi: 10.1099/00222615-48-3-253

Weatherspoon-Griffin, N., Zhao, G., Kong, W., Kong, Y., Morigen, AndrewsPolymenis, H., et al. (2011). The CpxR/CpxA two-component system up-regulates two Tat-dependent peptidoglycan amidases to confer bacterial resistance to antimicrobial peptide. J. Biol. Chem. 286, 5529-5539. doi: $10.1074 /$ jbc.M110.200352

Weiner, L., and Model, P. (1994). Role of an Escherichia coli stress-response operon in stationary-phase survival. Proc. Natl. Acad. Sci. U.S.A. 91, 2191-2195. doi: 10.1073/pnas.91.6.2191

Wolfe, A. J., Parikh, N., Lima, B. P., and Zemaitaitis, B. (2008). Signal integration by the two-component signal transduction response regulator CpxR. J. Bacteriol. 190, 2314-2322. doi: 10.1128/JB.01906-07

Wright, P. R., Richter, A. S., Papenfort, K., Mann, M., Vogel, J., Hess, W. R., et al. (2013). Comparative genomics boosts target prediction for bacterial small RNAs. Proc. Natl. Acad. Sci. U.S.A. 110, E3487-E3496. doi: $10.1073 /$ pnas. 1303248110

Yamamoto, K., Ogasawara, H., and Ishihama, A. (2008). Involvement of multiple transcription factors for metal-induced spy gene expression in Escherichia coli. J. Biotechnol. 133, 196-200. doi: 10.1016/j.jbiotec.2007.08.002 
Yang, X.-W., He, Y., Xu, J., Xiao, X., and Wang, F.-P. (2013). The regulatory role of ferric uptake regulator (Fur) during anaerobic respiration of Shewanella piezotolerans WP3. PLoS ONE 8:e75588. doi: 10.1371/journal.pone.0075588

Yao, H., Wang, Y., Lovell, S., Kumar, R., Ruvinsky, A. M., Battaile, K. P., et al. (2012). The structure of the BfrB-Bfd complex reveals protein-protein interactions enabling iron release from bacterioferritin. J. Am. Chem. Soc. 134, 13470-13481. doi: 10.1021/ja305180n

Yohannes, E., Barnhart, D. M., and Slonczewski, J. L. (2004). pH-dependent catabolic protein expression during anaerobic growth of Escherichia coli K-12. J. Bacteriol. 186, 192-199. doi: 10.1128/JB.186.1.192-199.2004

Yoshida, T., Qin, L., Egger, L. A., and Inouye, M. (2006). Transcription regulation of $o m p F$ and $o m p C$ by a single transcription factor, OmpR. J. Biol. Chem. 281, 17114-17123. doi: 10.1074/jbc.M602112200

Zahrl, D., Wagner, M., Bischof, K., and Koraimann, G. (2006). Expression and assembly of a functional type IV secretion system elicit extracytoplasmic and cytoplasmic stress responses in Escherichia coli. J. Bacteriol. 188, 6611-6621. doi: 10.1128/JB.00632-06

Zhang, Z., Gosset, G., Barabote, R., Gonzalez, C. S., Cuevas, W. A., and Saier, M. H. (2005). Functional interactions between the carbon and iron utilization regulators, Crp and Fur, in Escherichia coli. J. Bacteriol. 187, 980-990. doi: 10.1128/JB.187.3.980-990.2005
Zhao, K., Liu, M., and Burgess, R. R. (2005). The global transcriptional response of Escherichia coli to induced $\sigma 32$ protein involves $\sigma 32$ regulon activation followed by inactivation and degradation of $\sigma 32$ in vivo. J. Biol. Chem. 280, 17758-17768. doi: 10.1074/jbc.M500393200

Zhao, K., Liu, M., and Burgess, R. R. (2007). Adaptation in bacterial flagellar and motility systems: from regulon members to "foraging"-like behavior in E. coli. Nucleic Acids Res. 35, 4441-4452. doi: 10.1093/nar/gkm456

Zhou, J., and Rudd, K. E. (2013). EcoGene 3.0. Nucleic Acids Res. 41, D613-D624. doi: $10.1093 /$ nar/gks 1235

Conflict of Interest Statement: The authors declare that the research was conducted in the absence of any commercial or financial relationships that could be construed as a potential conflict of interest.

Copyright (c) 2017 Baron, Bonnassie, Alabdeh, Cochet, Nau, Guérin-Dubiard, Gautier, Andrews and Jan. This is an open-access article distributed under the terms of the Creative Commons Attribution License (CC BY). The use, distribution or reproduction in other forums is permitted, provided the original author (s) or licensor are credited and that the original publication in this journal is cited, in accordance with accepted academic practice. No use, distribution or reproduction is permitted which does not comply with these terms. 